\title{
Disruptions and resilience in global container shipping and ports: the COVID-19 pandemic versus the 2008-2009 financial crisis
}

\author{
Theo Notteboom ${ }^{1,2,3} \cdot$ Thanos Pallis $^{4} \cdot$ Jean-Paul Rodrigue ${ }^{5}$
}

Accepted: 14 November 2020 / Published online: 4 January 2021

(C) The Author(s), under exclusive licence to Springer Nature Limited part of Springer Nature 2021

\begin{abstract}
Economic shocks test the resilience and adaptability of the shipping industry and container ports. Each crisis triggers different ramifications in the container market. This paper investigates the temporal and spatial sequences of the supply and demand shocks of COVID-19 on container ports and the container shipping industry by comparing these events to the 2008-2009 financial crisis. Using operational and financial data from primary and secondary sources, we analyze short-term impacts and their differences, the reasons for these variations, and the evolution in the adaptive capacity and resilience of ports, terminal operators, and carriers. The analysis revolves around several inter-related domains: impacts on global supply chains; impacts on operational aspects, market structure, and strategic behavior of shipping lines and terminal operators; impacts on port activity levels in terms of vessel calls and container volumes handled; and network impacts in terms of changes in aspects of container port connectivity. The changes observed and the strategic behavior of the market players involved reveal that further adaptation mechanisms, such as slow steaming, economies of scale, and capacity management, have been applied differently between the financial crisis and COVID-19, resulting in different outcomes. For an external shock such as COVID-19, impacts are the outcome of how ports and the shipping industry fit within complex supply chains and the cargo composition handled by ports.
\end{abstract}

Keywords Ports $\cdot$ Maritime shipping $\cdot$ Supply chains $\cdot$ Shocks $\cdot$ Resilience . Pandemics · COVID-19

Theo Notteboom

theo.notteboom@ugent.be

1 Maritime Institute, Faculty of Law and Criminology, Ghent University, Ghent, Belgium

2 Faculty of Business and Economics, University of Antwerp, Antwerp, Belgium

3 Antwerp Maritime Academy, Antwerp, Belgium

4 Department of Shipping, Trade and Transport, University of the Aegean, Chios, Greece

5 Department of Global Studies and Geography, Hofstra University, Hempstead, NY, USA 


\section{Introduction}

Each crisis reveals the weaknesses of a system and tests its resilience. The COVID19 pandemic led to the second global crisis since the 2008/2009 financial crisis, which resulted in a recession in all OECD countries and most emerging economies. It fundamentally challenged the direction of future trade flows and trade agreements. The stability of global financial institutions, sustainable GDP growth, the reliance on OECD economies as major importers, government economic interventions, and widely applied logistics concepts such as just-in-time were being questioned. From a business cycle perspective, periods of growth are commonly followed by adjustment phases where misallocations are corrected. This readjustment phase was felt in the aftermath of the 2008-2009 financial crisis that substantially impacted maritime shipping companies and port terminals.

The COVID-19 pandemic presents new and unprecedented impacts on global supply chains and on the port and shipping industry. Any sudden drop in consumer demand has an immediate impact on shipping and port operations activity levels and may alter corporate strategies or even market structures. This paper discusses the main implications of the COVID-19 pandemic on container ports, terminal operators, and shipping lines. It investigates the temporal and spatial sequences of the supply and demand shocks of COVID-19 and compares these events with the 2008-2009 financial crisis. The scope of this comparison is to understand whether the COVID-19 pandemic and its implications differ from the implications of major shocks of a similar scale, to explore the reasons for any variations, and to assess how maritime industries have built resilience, if they have, and whether they are now better prepared to face supply, demand, and distribution shocks.

The analysis revolves around two central research questions: (1) what are the short-term implications of COVID-19, and (2) how do these short-term implications compare with the economic-financial crisis of 2008/2009? These two questions are applied to several strategic and operational aspects of supply chains, container shipping, and ports. In particular, to understand the implications of the shock produced by the COVID-19 crisis, we examine indicators and measures dealing with three interrelated aspects using primary and secondary sources: (1) data on container shipping operations, (2) port demand data, and (3) financial and strategy data for shipping lines and terminal operators. To extract conclusions on the impact of the COVID-19 pandemic, the analysis of the above data is complemented with the discussion of qualitative survey data collected from world ports from April 2020 to October 2020 in the context of the WPSP/IAPH COVID-19 Barometer reports. ${ }^{1}$

\footnotetext{
1 In March 2020, the World Ports Sustainability Program (WPSP) and the International Association of Ports and Harbors (IAPH) set up a COVID-19 Task Force to monitor the impacts of COVID-19 on ports and to facilitate information exchange between ports on procedures and practices in dealing with COVID-19. The IAPH-WPSP COVID-19 task force took the initiative to launch an "IAPH-WPSP Port Economic Impact Barometer" to gather information on the short-term impacts of COVID-19 on ports in the area of vessel calls, hinterland transport, distribution activities, procedures, and staff availability. This resulted in the publication of periodical Barometer reports in the period since April 2020 and a half-year report in September 2020 (Notteboom and Pallis 2020).
} 
The results of this analysis are compared with the situation in 2009 at the onset of the financial crisis. This comparative analysis identifies similarities and differences between the short-term implications of two major economic crises of the first part of the 21 st century, regarding shipping operations, port activity levels, and corporate strategies of shipping lines and terminal operators. Considering the endogenous features of the financial crisis of 2008/2009 and the exogenous nature of the COVID-19 pandemic, it is relevant to conceptualize the resilience of maritime supply chains to shocks of comparable scale but differing in nature.

The paper examines five inter-related domains. These are the impacts of the COVID-19 pandemic on global supply chains (Sect. 2), on operational aspects, market structure, and strategic behavior of shipping lines (Sect. 3), on global terminal operators (Sect. 4), on port activities in terms of vessel calls and container volumes handled (Sect. 5), and on aspects of port connectivity that co-define shipping networks, such as vessel sizes and deployment capacity hosted by ports (Sect. 6). The study concludes (Sect. 7) with the major similarities and divergences between the two most recent global crises - the financial crisis of 2008-2009 and COVID19-in terms of disruptions and resilience within shipping, terminals, and ports. This analysis does not detail the macroeconomic impacts of the pandemic on GDP growth, trade flows, and related spatial patterns of economic activity. Instead, it empirically investigates (a) how changes in economic demand and supply that are considerable in magnitude, global in scale, and unexpected in terms of timing, eventually trickle down to maritime supply chains, container shipping, and port activity, and (b) whether, and how, corporate strategies and operations in these industries have demonstrated the capacity to adapt and be resilient to substantial supply and demand shocks.

\section{A supply chain perspective on the impact of the COVID-19 crisis}

\subsection{Sectoral and sequential implications of disruptions}

Economic and financial disruptions are recurring events impacting supply chains, with pandemics considered low probability and high impact events (Luke and Rodrigue 2008). The most common are recessions that have a severity ranging from light, where economic decline (e.g., GDP) may last a short period (a few months), to severe, where economic decline is steep and may last several years (commonly known as a depression). There is an abundance of economic literature assessing the impacts of recessions on trade, industrial production, and consumption patterns, particularly at the onset of the 2008/2009 financial crisis (e.g., Hoff and Stiglitz 2001; Bems et al. 2010). This severity will imply various levels of decline in consumption, trade, and transportation activity (Fig. 1).

Changes (declines) in consumption patterns (demand) are related to the type of goods and related services. In an advanced economy, expenditures on consumer goods typically account for two-thirds of the GDP. Basic goods (also labeled essential goods such as food and household items) and luxury goods (fashion items) tend to be the most resilient. Respective supply chains are thus impacted marginally by 


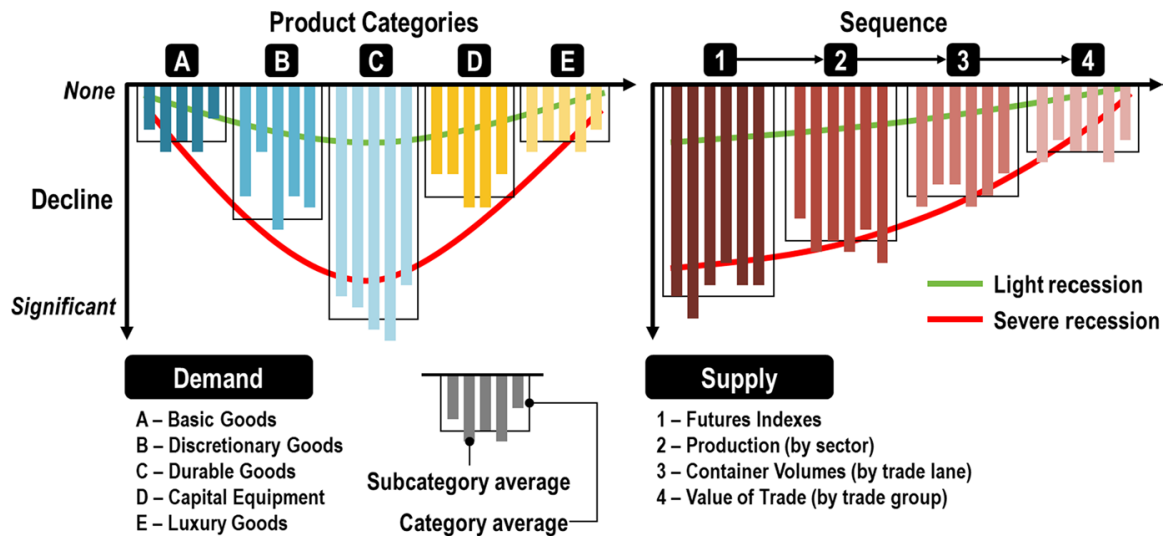

Fig. 1 Impact of recessions on consumption, production, and trade Source: authors' compilation adapted from De Monie et al. (2010)

recessions. However, recessionary forces can have significant impact on the demand for durable goods (e.g., cars, appliances, computers), discretionary goods (e.g., electronics, apparel), and capital equipment (e.g., ships, trucks, machinery, and port infrastructure). During recessions, consumers lose a significant share of their discretionary spending capacity, implying the postponement in spending, particularly for durable goods. Corporations, seeing a decline in the demand, reduce their spending on capital equipment accordingly. Further, to reduce risks, they also reduce their inventory levels.

Trends observed in global ports since the outbreak of the COVID-19 pandemic confirm the resilience of the demand for basic goods, particularly foodstuff and medical products (Fig. 2). Similar was the impact of the 2008/2009 financial crisis on goods shipped in containers (Pallis and de Langen 2010). The effect on containerized food (such as fruit, dairy products, canned food, and perishables such as seafood, vegetables, fruit, and meat) was somewhat limited, as the consumption of (supermarket) food provisions was noticeably impacted by the recession (Mintel International 2009). During the lockdowns, even supermarkets in some countries had to switch to online sales of non-essential goods such as electronics or clothing. Governments wanted to guarantee a level playing field with retailers that were ordered to close. The quantities of consumer goods shipped were moderate, influenced by changes in both consumption and reduced inventory levels. Flows of intermediate goods, such as chemical products and parts used in products such as paint, plastics, medical equipment, capital goods (e.g., machinery), and durable consumer goods (e.g., cars, televisions), declined dramatically (Pallis and de Langen 2010).

Changes in production, transportation, and trade (supply) are taking place along a sequence of events. The first of these events concerns future indexes such as stock market valuations, commodity prices, and freight rates-indicators that quickly react to changing market conditions. Interpreting these indicators (repricing of inputs and assets and the anticipated drop in demand), manufacturers are incited to curtail their production and the related demand for parts and raw materials. These adjustments 


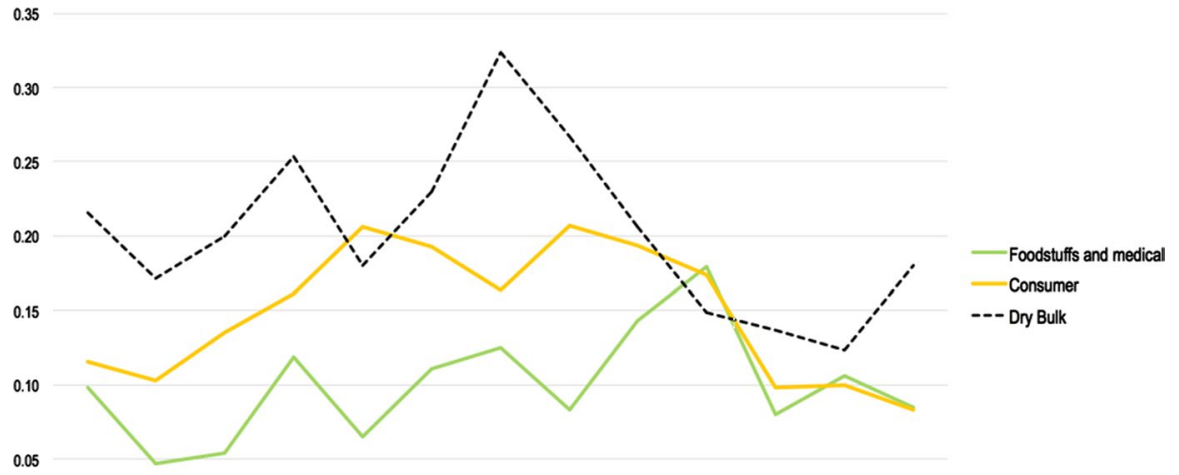

0.00

Week-15 Week-16 Week-17 Week-18 Week-19 Week-20 Week-21 Week-23 Week-25 Week-27 Week-29 Week-36 Week-41

Fig. 2 Share of ports reporting capacity underutilization compared with normal activity during Weeks 15-41 of 2020 Source: based on WPSP-IAPH surveys on the impact of COVID-19 on world ports, as reported in Notteboom and Pallis (2020)

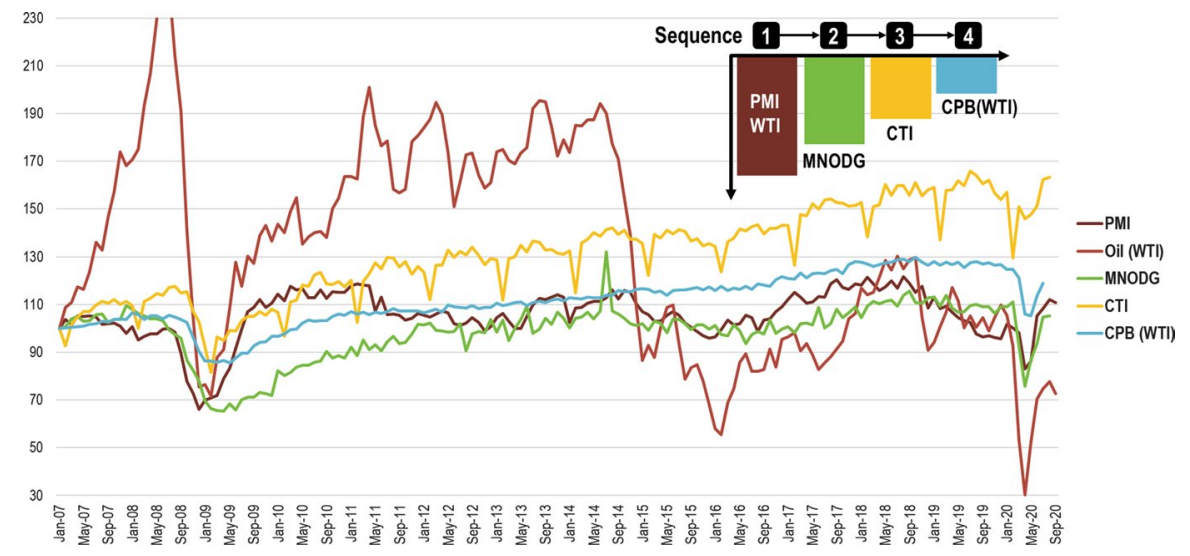

Fig. 3 Selected supply chain and trade indicators, 2007-2020 $(2007=100)$. Note PMI Purchasing Managers Index, WTI West Texas Intermediate, MNODG manufacturers new orders of durable goods, $C T I$ Container Throughput Index, $C P B(W T I)$ World Trade Index (volume) Source: authors' compilation based on data from the Federal Reserve Bank of St. Louis, the Council of Supply Chain Management, the Institute of Shipping Economics and Logistics (ISL), and CPB World Trade Monitor

occur differently in different sectors, depending on whether these are supplying discretionary goods or capital equipment. Afterwards, container volumes and global trade confirm the subsequent collapse of the material economy with a substantial decline in merchandise trade.

Figure 3 depicts key indicators allowing for a comparison between the financial crisis of 2009 and COVID-19. The financial crisis was an internal shock caused by a misallocation of capital and investments that led to massive cross-defaults when 


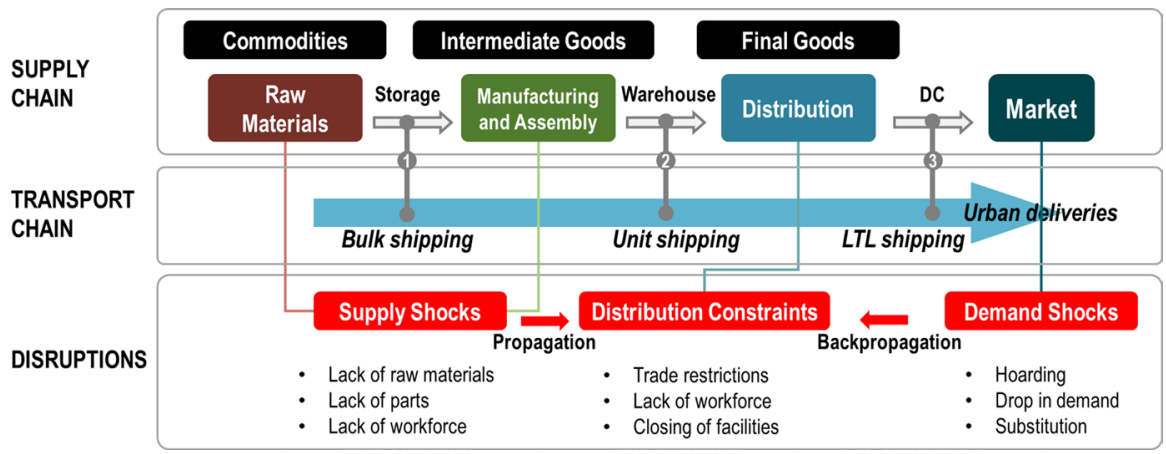

Fig. 4 Impacts of disruptions on supply chains Source: authors' compilation

assets were repriced. This implies that indicators such as oil prices ${ }^{2}$ and the PMI were the first to decline. As repricing and demand changes spread through the economic system, durable goods orders declined, closely followed by container volumes and international trade. As the economic shock was absorbed, the leading indicators recovered, but recessionary conditions endured for over 2 years.

For COVID-19, the situation is very different since it concerns an external shock that rapidly impacted all elements of the supply chain roughly at the same time. Thus, the main difference between the financial crisis of 2008-2009 and COVID-19 concerns the high level of synchronism of the indicators at the onset of the pandemic. All of them declined at the same time and to a similar extent. However, unlike the financial crisis, there was a fast rebound of the indicators within 3 months, supporting the thesis of temporary disruptions and deferred demand. With economic trends in Europe heading in a different direction from the positive trends in other parts of the world (i.e., China), it remains to be seen whether the pandemic may recreate financial crisis conditions, creating a countershock and a recession resulting from internal conditions such as high unemployment and low demand. The economic aftermath of the COVID-19 crisis will partly be shaped by the effectiveness of government aid packages and their longer-term impacts on government budgeting and taxes.

\subsection{Supply chain implications of disruptions}

Supply chains can be very complex, composed of a series of stages, from the provision of intermediate goods to final goods consumption in consumer markets. Disruptions within supply chains take place in three fundamental ways (Fig. 4).

Supply shocks represent an unexpected sudden change in the availability of raw materials, parts, and manufacturing capabilities. It is not just that prices may surge, but the availability of essential components can vanish because of a lack of raw materials,

\footnotetext{
${ }^{2}$ Note that (spot) oil price volatility is not only caused by economic shocks, but depends on an array of economic, technical, financial, and geopolitical parameters (see Drachal, 2016; The Economist, 2020).
} 
parts, or lack of labor necessary for their procurement. Depending on the existing buffer, such as stockpiles of energy, grain, parts, or raw materials, the supply shock can take some time to be felt across a supply chain.

Demand shocks imply a sudden change in demand due to unforeseen circumstances. For several items such as food, expectations can lead to hoarding which, in turn, may trigger a temporary surge in demand, with several items becoming unavailable. The consumption of discretionary items such as cars, clothing, furniture, or appliances is usually deferred, and the demand for energy declines on par with passengers and freight mobility. Notable exceptions include medical equipment and pharmaceuticals that see a surge during a pandemic. Consumers undertake a substitution of their consumption patterns towards essential goods and shift their consumption depending on the scarcity and price of items. Restaurants and caterers may be obliged to substitute their services to alternative forms such as takeouts and home deliveries, as was indeed the case with the European lockdowns during the second wave of November 2020. There were also unique surges and resilience in the consumption of specific product groups such as computers (surge in tele-working and tele-education).

Distribution capabilities can be impaired by restrictions on trade, the lack of a workforce, or the closing of key distribution facilities such as airports, ports, or distribution centers. This implies that existing inventory could be unavailable because of the lack of distribution capabilities. So, even if production capabilities could be present, the lack of distribution capabilities can create shortages irrespective of the demand. As last-mile distribution relies much more on labor than prior stages, there is a much higher risk of disruptions through labor absenteeism due to illness. Following substantial changes in demand, major distributors, such as e-commerce retailers, will modify their procurement strategies to focus on high demand items while discontinuing the procurement of discretionary items.

Shocks can propagate or backpropagate within supply chains, depending on where they occur. A single propagation is usually common, such as when a weather event or a strike takes place. Such events are well documented since they involve a readily identifiable component or segment of a supply chain. However, propagation and backpropagation mechanisms simultaneously take place on a vast scale in case of significant natural disasters (see, e.g., Todo et al. 2015 on the supply chain impacts of the Great East Japan Earthquake of 2011), political revolutions (e.g., the Arab Spring revolution or the break up of the Soviet Union), financial shocks (e.g., the Great Depression), or global health crises. During a pandemic, the coevolution of propagation and backpropagation mechanisms creates several concurrent shocks. For instance, the hoarding of food, paper goods, and cleaning supplies transfer the inventory from distribution centers to the final market (e.g., consumer homes) in such a short amount of time that the manufacturing and distribution capabilities cannot cope.

\subsection{Sequential supply chain disruptions}

From a supply chain perspective, COVID-19 is unfolding in several sequential phases. The first phase, in early 2020, consisted of a supply shock in China where lockdown measures resulted in a de facto extension of sharply decreased Chinese 
production during the New Year's period. The lockdown affected most of the workforce and curtailed the industrial base between mid-January and early March 2020 (Knowler 2020a). Simultaneously, some sectors faced shortages (pharmaceuticals and medical equipment) due to a demand surge and the diversion of inventories (World Health Organization 2020).

The second phase began in mid-March 2020 and consisted of a (global) demand shock with backpropagation along supply chains (Baschuk 2020; World Trade Organization 2020). Various lockdown measures implemented across the world resulted in a decline in global (derived) demand because of lower consumer and industrial confidence and limited retail activity. Service activities associated with the provision of transport services, such as tourism, almost vanished in the first half of 2020. Except for the temporary hoarding shock on inventories, the demand for most consumer products saw a sharp decline. The lockdown of a large consumer base removed people from the workforce and shifted consumption patterns to essential goods (food and personal items). The collapse of travel, tourism (cruise industry), and the entertainment industry, ${ }^{3}$ as well as the temporary closure of bars and restaurants, had additional depressing effects on demand.

Last-mile vulnerabilities in distribution became visible because of the lower availability of the workforce (e.g., absenteeism in trucking). The lower economic activity level and uncertainty about the path to economic recovery also contributed to a steep drop in the price of several commodities. The shift to e-commerce accelerated a process that was already taking place, pressuring online retailers with additional demands. Segments of the luxury sector vanished because of the lockdown, particularly tourism, creating severe disruptions in their supply chains.

The highly uncertain environment of fast-rising unemployment, government rescue packages, and market volatility in the first half of 2020 was followed by a recovery that took root in the third quarter of 2020 , with highly uncertain conditions generated by a new wave of COVID-19 cases and restrictions in countries around the world. Every major forecasting institution (e.g., IMF, World Bank, OECD) revised their expectations about future growth, as was the case during the financial crisis of 2008-2009.

These observations suggest that we are far from reaching the final phase of a clear and consistent recovery and returning to normal demand patterns. Since September 2020, several parts of the world (such as North America) are witnessing a clear trend toward restocking inventories at distribution centers and stores. However, once this restocking is completed, there will be a rebalancing of supply and demand to a "new normal." The recovery phase might go hand in hand with an increased risk of protectionism to support national production. Many economies will be in a situation of depressed demand and high unemployment. Moreover, nearshoring and reshoring strategies are being considered to reduce the dependence on overseas production, develop essential economic activities at a regional/local level, and increase supply chain resilience (Notteboom and Haralambides 2020). The singularity of COVID-19 remains to be assessed.

\footnotetext{
3 An exception being home-entertainment streaming platforms such as Netflix and Amazon Prime.
} 


\section{The adaptive capacity of container shipping lines}

Container shipping is a capital-intensive industry where assets are owned or leased. Asset management of the fleet they own or operate is a key component of the operational and commercial success of container shipping lines. However, fleet capacity management is complex given the inflexible nature of vessel capacity in the short run due to fixed timetables, making it hard to react effectively to structural shocks in demand for container transport. The uncertainty and volatility in the container shipping market and the associated need for resilience has received attention in the literature, but assessment of the ramifications of COVID-19 is lacking and will become more apparent as the situation unfolds. Notteboom et al. (2010) and Chen et al. (2012) analyzed the strategies of the international container shipping industry during the period of the financial crisis, which did not lead to an industry rationalization despite high vessel overcapacity levels, rate erosion, and poor financial performance. Corporations use a range of strategies and management tools to adapt to events in the market environment and to demonstrate higher levels of flexibility and resilience (Notteboom and Lam 2014). Container shipping companies are incited to develop technological and process-driven innovative solutions and innovations in value creation and business models to create sustainable and resilient shipping (Yang et al. 2019). In applying the notion of organizational resilience to shipping lines, Bhaskar et al. (2019) found that they may exhibit different modularity levels and diverse responses. Against this background, this section compares the impacts of the financial crisis and the COVID-19 pandemic on container shipping and the behavior of the carriers.

\subsection{The impact of the $\mathbf{2 0 0 8 / 2 0 0 9}$ crisis on liner shipping}

The financial-economic crisis, which started in the fall of 2008, provides a salient example of the difficulties the container shipping industry has traditionally faced in adapting fleet capacity to rapidly changing market conditions (cf. Fusillo and Haralambides 2020) The crisis generated a large surplus of cargo capacities, particularly on the Europe-Asia and Transpacific routes. World container shipping demand in TEU-mile fell by $12.4 \%$ in 2009 . Shipping lines made several attempts to adapt to an enduring situation of overcapacity:

- Order postponements or cancellations and vessel scrapping: In late 2008, several shipping lines started to postpone and cancel orders, and scrap older ships. The total number of cancellations of containership orders amounted to 140 ships, or 436,000 TEU, between the start of the financial crisis in September 2008 and mid-February 2010 (Alphaliner 2010a). Cancellations represented $6.7 \%$ of the containership order book in October 2008.

- Vessel layup: In mid-April 2009, the worldwide laid-up fleet totaled about 1.3 million TEU, or $10.4 \%$ of the world container fleet, and reached more than $12 \%$ in the Autumn of 2009. The idle containership fleet decreased to $9.9 \%$ of the 


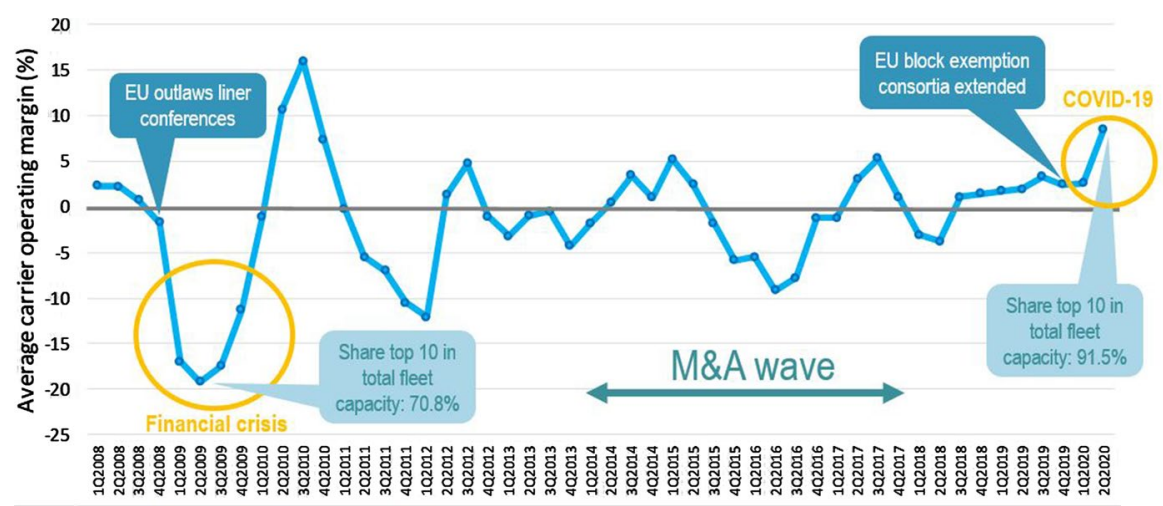

Fig. 5 Average operating margins of main container carriers by quarter, 1Q 2008 to 2Q 2020. Notes Average of CMA CGM (incl APL to 2Q 2016), CSCL (to 1Q2016), COSCO (from 3Q 2018), Evergreen, Hanjin (to 3Q 2016), Hapag-Lloyd (incl CSAV to 2014), HMM, Maersk, ONE (from 2Q 2018, formerly K-Line, MOL and NYK), Wan Hai, Yang Ming, and Zim. MSC, the world's second-largest container shipping company, does not report on financial results given its family-owned nature Source: authors' compilation based on Alphaliner data

world fleet capacity in February 2010 (508 ships totaling 1.3 million TEUAlphaliner 2010b).

- Suspension of liner services, particularly on the Far East-Europe and transpacific trade routes: Total capacity in Far East-Europe trade fell by $21 \%$ between October 2008 and March 2009. This corresponded to a net withdrawal of 19 liner services, with only 45 services left between Europe/Med and the Far East in March 2009 (figures Alphaliner).

- Slow steaming: Initially, shipping lines introduced slow steaming in 2007 to offset the rise in bunker costs (Notteboom and Vernimmen 2009), but the slow steaming option remained popular even after a steep decline in bunker prices from the peak of USD 700 in July 2008 to a low of USD 170 per ton in December 2009 (bunker price for IFO 380 grade in Rotterdam). Slow steaming absorbed about 300,000 TEU of vessel capacity, or $2.3 \%$ of the world container fleet in 2009.

Despite these efforts, the 2008/2009 financial crisis dramatically impacted profitability in the liner shipping market. Various analyses underlined an overall operating loss in 2009 of more than USD 20 billion (American Shipper 2009). ${ }^{4}$ Figure 5 shows that the industry average in terms of operating margin fluctuated between -17 and $-19 \%$ in the first three quarters of 2009. The poor financial situation of many carriers led to an array of bail-out and debt restructuring programs. Many

\footnotetext{
4 The most significant losses were recorded by Maersk (loss of USD 2.09 billion), Cosco (USD 1.14 billion), and Hapag-Lloyd (USD 839 million). The worst performers in 2009 in terms of operating margin included China Shipping Container Line (-32\%), Cosco (-28.4\%), Zim (-27.6\%), and Yang Ming $(-20.1 \%)$. The worst performer of all was CMA CGM with profits plunging $87 \%$.
} 
liner companies resorted to raising capital to strengthen balance sheets and seize opportunities or simply to survive. ${ }^{5}$

The relatively inelastic nature of the demand for shipping services constitutes a core problem for the financial performance of container shipping lines (Graham 1998; Fusillo 2006; Notteboom 2012). These financial results were not only caused by exogenous factors (i.e., drop in demand) but also by the endogenous behavior of shipping lines, such as continued investment in new (mega) vessel capacity. Shipping lines faced difficulties adjusting vessel capacity to meet short-run demand, resulting in rate erosion and low vessel utilization. With the benefit of hindsight, it can be concluded that, if the container shipping industry had acted rationally on indicators such as aggregate ship orders, scrapping, and utilization levels, it could have significantly reduced volatility through collective capacity management. With the outlawing of liner conferences in Europe since October $2008,{ }^{6}$ market-related information about capacity deployment, demand/supply dynamics, and pricing of liner services became scarcer. Therefore, there was no longer a stabilizing mechanism in terms of freight rates and joint capacity management. Existing strategic alliances among shipping lines at that time (i.e., New World Alliance, Grand Alliance, and CKYH alliance (Notteboom et al. 2017) were not able to roll out effective capacity management programs to significantly reduce fleet capacity in line with the observed drop in demand. Container shipping entered a period of depressed freight rates partly due to poor capacity management and the lack of any rationalization in the industry. Major mergers and acquisitions (M\&As) only started in 2014, and the bankruptcy of Hanjin took place in 2016. In an environment of overcapacity and high fixed costs, shipping lines were chasing short-run contributions filling ships at a marginal cost, leading to direct operational losses on the trades considered.

\subsection{The COVID-19 pandemic: a higher carrier resilience?}

The situation was radically different during the COVID-19 pandemic, as container lines adjusted their strategy to cope with the drop in volumes. Freight rates did not erode in the first half of 2020. Freight rates on the Asia-Europe trade even reached a 4-year record in October 2020, with Asia-Med rates hitting a 5-year record. Transpacific rates also remained at record high levels in September-October 2020. The evolution of the Shanghai Containerized Freight Index illustrates the rise of freight rates far above the 2016-2019 levels since week 21, about ten weeks after the WHO declared COVID-19 a pandemic on March 11, 2020 (week 11). Even during the

\footnotetext{
${ }^{5}$ Examples included a share placement of USD 1.58 billion by Maersk Line, a capital injection of USD 755 million in ZIM Line, and a bond issue of USD 640 million by NYK.

6 In 1986, the European Union (EU) Council Regulation 4056/86 allowed liner shipping operators an exemption from EU competition rules to organize themselves into conferences with the aim of fixing prices and coordinating capacity for the transport of containerized cargo. In September 2006, the EU Council decided to abolish this exemption, with effect from 18 October 2008 (decision by EU Council of 25 September 2006, Regulation (EC) No 1419/2006).
} 


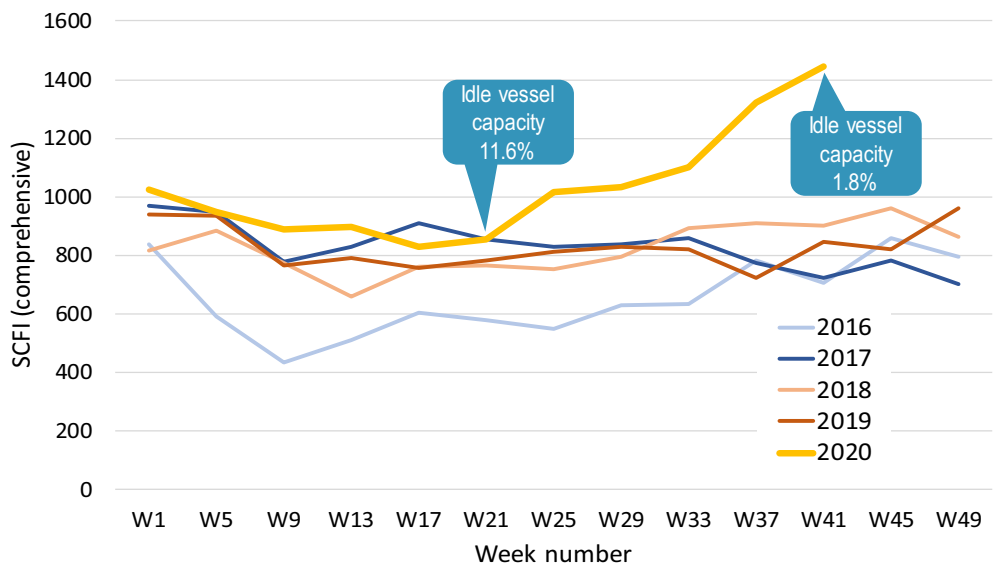

Fig. 6 Shanghai Containerized Freight Index or SCFI (comprehensive), W1 2016 to W41 2020. Note The SCFI moves up and down based on weekly spot rates of the Shanghai export container transport market based on data compiled from 15 different shipping routes. The Shanghai Containerized Freight Index (SCFI) is published for each of these routes, but here we show the comprehensive index covering all routes (weighted average). The SCFI's spot rate fluctuates not on real-time rates, but on what carriers intend to charge Source: authors' compilation based on data Shanghai Shipping Exchange; idle vessel capacity figures were obtained from Alphaliner

Chinese lockdown in early 2020, the SCFI index remained higher than in the previous 4 years (Fig. 6). In the third quarter of 2020, volumes and rates surged. ${ }^{7}$

Carriers resorted to capacity management, which explains this sharp contrast with the situation in 2008/2009 when rates plunged. The combination of strong market consolidation, particularly the 2014-2017 M\&A wave, improved capacity management, and a fast bounce-back in demand post-lockdown generates optimism on the short-term impact of COVID-19 on carrier results. Despite the lower liftings, most liners have reported H1 earnings far above earlier expectations. This was further facilitated by sharing slots on vessels, a stagnant orderbook, returns of chartered tonnage to lessors, low bunker fuel prices, and, to a lesser extent, by the lack of regulations allowing liner shipping lines to manage and control capacity (Pelagidis and Haralambides 2020).

Despite the pandemic, shipping lines and their alliances (i.e., The Alliance, Ocean Alliance, and 2M) maintained network integrity and resorted to blanked sailings to deal with declining demand. In February 2020, the supply shock in China

\footnotetext{
7 Inbound volumes to the US West Coast were robust, caused by inventory restocking expanded by the conventional peak in the retail imports season. Spot freight rates on the China-US West Coast trade in Q3 2020 were roughly double Q2 2020 levels and almost triple than Q3 2019. The Europe-Far East trade also showed a healthy recovery in terms of volumes and rates. Unexpectedly high cargo demand has also pushed up spot rates on North-South routes to Africa and South America. According to the Shanghai Containerized Freight Index (SCFI), rates from Shanghai to Santos were USD 3,952 per TEU in mid October 2020, seven times the rate in late August. In early October 2020, Shanghai-Durban hit a record high of USD 1737 per TEU and Shanghai-Lagos hit a record high of USD 3293 per TEU.
} 
generated the first wave of blank sailings, involving the withdrawal of some $36 \%$ of Asia to Europe sailings, and $28 \%$ of transpacific head haul capacity. In March, the cargo scheduled to be transported from the Far East was further delayed by national lockdowns in destination countries and the reluctance of consignees to collect cargoes. Given the sailing time on the Europe-Far East trade, the effect of these blank sailings could only be observed in European ports by March 2020. In April/May 2020, when lockdowns and restrictions on economic activity in Europe and North America halted industrial production, with consumer and business demand reaching record lows, carriers were withdrawing up to $20 \%$ of their network capacity on the main trade lanes and idling more than 2.7 million TEU of fleet capacity, or more than $11 \%$ of the world container fleet. The blank sailings rate for the Asia-United States route reached $19 \%$ of canceled capacity in May (47 out of 249 calls were blanked). As a result, the share of vessel layups reached peaks comparable with those of 2009.

However, the average vessel utilization rate did not plunge, as was the case during the financial crisis. For some ports, the blank sailings implied $20 \%$ to even up to $50 \%$ fewer vessel calls between April and June 2020, although, for most ports, the impact was mainly visible on the main trade routes (e.g., Far East-Europe) and not so much on other trade routes. As analyzed in Sects. 5 and 6, blank sailings also had a direct effect on call sizes and, most notably, the number of containers handled per call, both issues causing operational hurdles to many ports. Carrier announcements in early June $2020^{8}$ were suggesting a cancellation rate for Q3 2020, reaching at least $20 \%$ of originally planned sailings (Knowler 2020b). However, in June/July 2020, blank sailings were curtailed as demand on some trade routes resumed due to relaxing COVID-19 measures in major North American and European markets. The recent surge in freight rates is directly associated with a peak growth in demand (i.e., restocking of inventories). Shipping lines drastically reduced the number of blank sailings to accommodate the demand growth: the share of idle vessels in total fleet capacity decreased from $11.6 \%$ in May 2020 to only $1.8 \%$ in October 2020 (Fig. 6).

Carriers further controlled vessel capacity by shrinking their orderbooks, increasing vessel scrapping activity (with even several post-Panamax vessels of around 10,000 TEU sent to the scrapyards), and by the occasional use of the Cape route around South Africa instead of the Suez Canal route. ${ }^{9}$

In addition to blank sailings, in the early months of COVID-19, shipping lines innovated with new service and storage solutions to minimize booking cancellations. They implemented programs to slow the flow of trade for shippers who were unable to take deliveries amid the crisis, with "suspension of transit", "detention in transit", or "storage in transit" clauses, allowing customers to adjust delivery dates

\footnotetext{
${ }^{8}$ Various reports based on Sea intelligence data. For example: Leonard (2020). Blank capacity nears 4 M TEUs with carriers planning Q3 cancellations, 8 June 2020. www.supplychaindive.com.

9 The same practice was used in early 2009. At that time, the Suez Canal transit fees were not competitive compared to the Cape route due to a combination of poor vessel utilization, low freight rates, and low bunker prices. During the first half of 2020, the practice of using the Cape route was less widespread as freight rates and vessel utilization levels were higher, so that route choice became primarily an issue of bunker costs.
} 
(example: MSC 2020). This provided flexibility and substantial cost savings, as it enabled shippers to better control storage costs at the point of booking, while adapting the delivery date to their own needs.

The composition of the container shipping fleet, characterized by a large number of very large container ships having entered the market in recent years due to economies of scale, imposed a very specific restructuring of services that promoted an increased utilization of large ships. ${ }^{10}$ Speed reduction (a cost-saving strategy extensively used following the financial crisis of 2008/2009) was not a part of the capacity management efforts, given that (super) slow steaming was already the norm with little room left for further speed reductions. These measures, combined with low bunker prices, positively impacted operating margins in the first half of 2020 (Fig. 5). All major carriers posted positive operating margins, in contrast to the 2008-2009 financial crisis.

In the longer term, the expected slow economic recovery and the ongoing gradual reorganization of global supply chains (e.g., nearshoring and reshoring) could push shipping lines to rationalize services on the main East-West trade routes while strengthening intraregional shipping networks. This trend was already evident, but one could see an acceleration in a post-COVID world.

The current crisis might also have an impact on market structure. The present level of consolidation in liner shipping is high with the top ten shipping lines controlling $91.5 \%$ of the total fleet capacity and all major carriers belonging to an alliance, ${ }^{11}$ see Fig. 5. While there has been some small M\&A activity (e.g., the $49 \%$ acquisition of Ignazio Messina shipping group by MSC), there are no immediate signs that a new wave of mergers and acquisitions will occur among larger carriers in the short- to medium-term. This is similar to the 2008/2009 crisis, which did not bring a new wave in M\&As in the container shipping industry, as there was no significant M\&A activity between October 2008 and early 2014. The most recent wave in carrier consolidation started in 2014 (Crotti et al. 2019), mainly due to the dramatic financial constraints suffered by container shipping companies after the 2008-2009 economic crisis, and given their large investments necessitated by the deployment of mega vessels. ${ }^{12}$ The starting position in 2020 is very different from 2009 as shipping lines have a much stronger financial position and credit ratings. The outlook of medium-term demand remains highly uncertain, with the long-term outlook anticipating carbon taxation and new fuel types. Some shipping lines might

\footnotetext{
${ }^{10}$ For example, in early July 2020, ONE (Ocean Network Express) recorded its highest loading of a 20,000 TEU class vessel while utilizing 97\% of the MOL Tribute's 20,100 TEU capacity World Cargo News (2020). Record box load for ONE. 8 July, 2020.

11 The three alliances (i.e., 2M, The Alliance, and Ocean Alliance) play a key role in capacity management on the main East-West routes. Alliances have been under legal scrutiny by the EU recently. In 2009, the EU adopted a Consortia Block Exemption Regulation [Commission Regulation (EC) No 906/2009], allowing shipping companies to operate joint liner shipping services. This Regulation was prolonged in 2014 by five years and was due to expire on 25 April 2020. After a lengthy and heated public consultation launched in September 2018, the EU decided in late 2019 to prolong the regulation for another 4 years until 25 April 2024 (see also Fig. 5).

12 The main recent takeovers and mergers include: the takeover of CCNI by Hamburg-Süd in 2014, the merger between Hapag-Lloyd and CSAV in 2014, the sale of the APL container division of NOL to CMA CGM by NOL in 2015, the merger between China Shipping and COSCO in 2016, the merger
} 
use their financial position to place more vessel orders (the order book is historically low) and expand their portfolios by acquiring regional niche carriers. It is noted that intraregional shipping services might play a more important role if reshoring and nearshoring trends intensify in a post-pandemic setting. Several container lines might also use their regained financial strength to intensify their focus on vertical integration through additional involvement in inland logistics and digital transformation while also continuing the greening of their fleets.

\section{Terminal operators: making the most of asset-based positions}

Two decades ago, the container handling sector was still relatively fragmented, whereas in recent years, the picture has drastically changed. The top ten operators in total container port throughput increased their share from $41 \%$ in 2001 to $70 \%$ in 2018 (Table 1). The terminal and stevedoring industry have expanded substantially in recent decades with the emergence of global container terminal operators controlling large multinational portfolios of terminal assets. Olivier et al. (2007) and Slack and Frémont (2005) made a distinction between two types of transnational corporations in the terminal industry: international terminal operators (ITOs) whose core expertise is linked to terminal operations, and ocean carriers whose core expertise is not in ports but in vertically related shipping activities. The financialization of the port and terminal industry (Rodrigue et al. 2011) added a third category of terminal operators, financial holdings (investment banks, pension funds, sovereign wealth funds) attracted by the port terminal sector as an asset class and for revenue generation potential (Notteboom and Rodrigue 2012).

In the early 2000s, the strong TEU growth of some of these corporate terminal networks was not only driven by strong demand and new greenfield terminal developments, but also by a series of large-scale acquisitions and multiple entries to boost expansion strategies, such as the takeover of CSX World Terminals in 2004 and P\&O ports in 2006 by DP World (Parola et al. 2013, 2015). The time scale of privatization and internationalization processes in the container terminal market accelerated as a result of port reforms across the world (Pallis et al. 2008) and the evolving balance of power between shipping lines and terminal operators (Parola and Musso 2007). As ports worldwide were facing terminal capacity constraints, financial holdings and independent terminal operators were paying record prices to acquire terminal assets (Rodrigue et al. 2011). The financial crisis led these actors to reassess risks and to move away from previous aggressive expansion strategies. After the 2009 crisis, carrier-related operators such as Cosco Shipping ports (part of China Cosco Shipping), TIL, and CMA CGM recorded the strongest growth in TEU throughput (Table 1).

Footnote 12 (continued)

between Hapag-Lloyd and UASC in 2016, the merger of NYK line, MOL, and K-Line in ONE (Ocean Network Express) in 2016, the take-over of Hamburg-Sued by Maersk Line in 2017, and the take-over of OOCL by COSCO in 2017. 


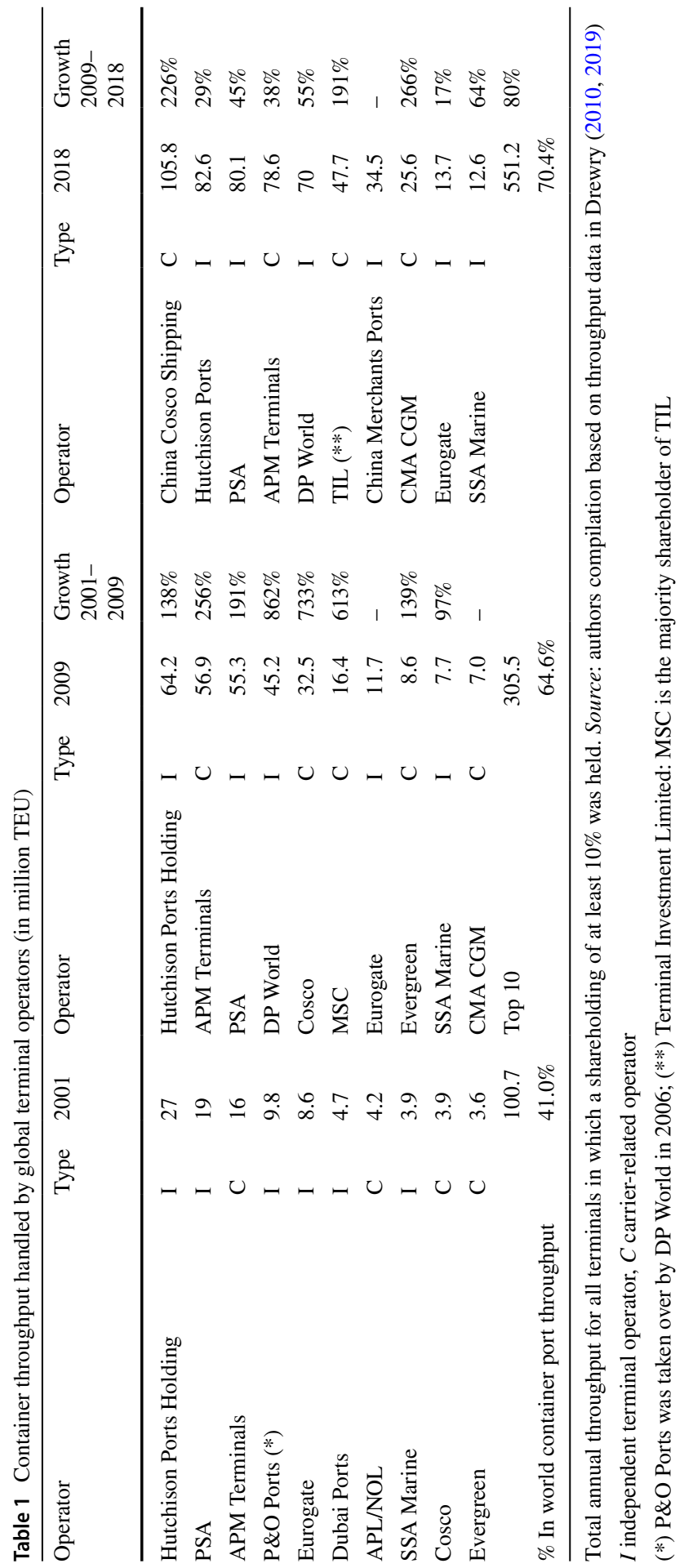

称 


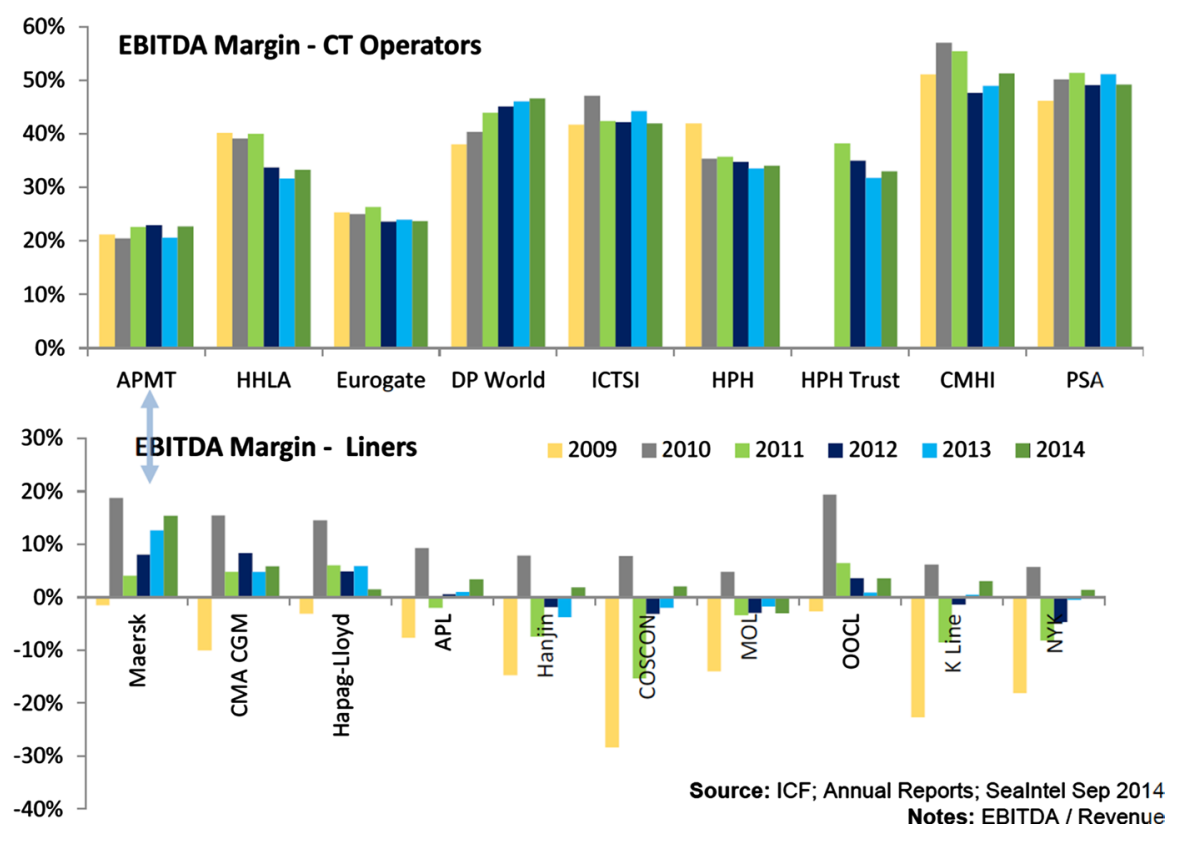

Fig. 7 EBITDA margin for container terminal operators and carriers, 2009-2014. Source: authors based on data Alphaliner, SeaIntel and annual reports

Demand shocks have an impact on the strategic and operational behavior of global terminal operators. Terminal operators are asset-based players (i.e., quay cranes, yard equipment). Global terminal operators typically financially outperform container shipping lines, which are also strongly asset-based. For example, during the financial crisis of 2008-2009 and in its immediate aftermath, the leading container terminal operators were able to achieve high and relatively stable EBITDA ${ }^{13}$ margins while shipping lines struggled with highly volatile and often negative margins (Fig. 7). EBITDA margins of terminal operators were hardly affected by the financial crisis, partly because they implemented a range of rationalization strategies (see Notteboom and Rodrigue 2012, for a detailed discussion).

Intensified cost control was adopted, including revisions of investment plans, equipment maintenance schedules, and asset deployment strategies. In a few cases, entire terminals were temporarily mothballed (e.g., the APMT Constantza terminal). The crisis changed how terminal operators think about equipment maintenance as this revealed a key area for realizing cost savings. Other cost measures included the deferral of concession fee payments and the renegotiation of existing concession agreements, particularly at the level of minimum traffic clauses.

The 2008-2009 crisis also prompted terminal operators to consider cancellation or postponement of terminal acquisition or construction projects, and ended their

$\overline{13}$ Earnings before interest, taxes, depreciation, and amortization. 
Terminal throughput growth in TEU

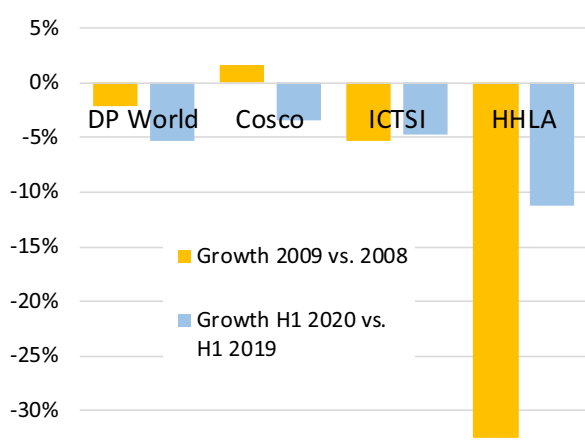

EBITDA margin

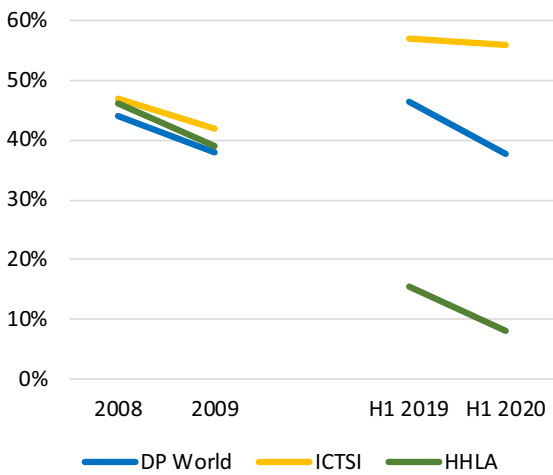

Fig. 8 EBITDA margin and TEU throughput for a selection of container terminal operators. Source: authors based on financial statements and data of respective operators

often aggressive geographical expansion and portfolio diversification strategies. To minimize risk, it thus became common practice to launch large terminal projects in phases, following developments in the demand for port services. Global terminal operators started to show a more careful and selective approach when bidding for new terminal concessions, or acquiring terminal assets and selecting partnerships. Since the 2008-2009 crisis, global terminal operators are also hedging risks by opting for more complex ownership and partnership structures. ${ }^{14}$ In developing a global expansion strategy, both independent- and carrier-related operators try to maintain competitive edge by building strongholds in selected ports, as well as through their often advanced know-how on the construction, management, and operation of container terminals.

Financial institutions remain cautious and have become more demanding on terms and project characteristics. Since the 2008-2009 crisis, it has become more common for terminal operators to sell stakes in terminal assets for financial relief, while keeping their role as operators. This commonly involves a financial holding seeking an opportunity to acquire terminal assets while leaving the existing terminal operator taking care of operations.

Like in 2008-2009, the COVID-19 pandemic affected in H1 2020 the volumes handled, but did not significantly impact EBITDA margins (see Fig. 8). Also, terminal operators adopted a mix of measures to minimize negative impacts. In the first months of COVID19, terminal operators faced an unintended terminalization of the inventory with high utilization levels of terminal yards. Many importers did not take ownership of the cargo since there were limited demand and the uncertainties of receiving the inventory in terms of labor costs and warehousing. Then, as demand remained low, the peak inventory situation at terminals eased. Another temporary

\footnotetext{
14 An example: Antwerp Gateway in the port of Antwerp (Belgium) is a joint-venture between DP World Antwerp Holding (60\%), Cosco (20\%), Terminal Link (10\%), and Duisport Group (10\%).
} 
consequence for terminals was a rebalancing of empty container flows. As demand dropped in North America and Europe, large volumes of empty containers were repositioned back to China and major exporters.

COVID-19 leaves ${ }^{15}$ terminal operators in a complex situation since their capacity cannot be changed (reduced) effectively. Their pricing power is reduced, and several will struggle to retain their added value activities. Most terminals are looking for additional clients, ships, and cargo. Like in 2008-2009, the changed economic situation means that terminal operators adopt a more cautious business prospects assessment. An extended period of economic slowdown may well result in some investors having to sell terminal interests. This may create opportunities for global terminal operators and financial investors with ready access to the necessary funds. The financing of large terminal projects might become more difficult to secure. However, partly because of land scarcity, ports continue to be considered long-term investments, and the COVID-19 pandemic will not impact this assessment.

\section{Port resilience: vessel calls, and cargo volumes}

The effects of COVID-19 on ports have been a short-lasting shock, which was of a lower scale and shorter duration than initially expected. This happened because of the adaptation capabilities demonstrated by both shipping lines/alliances and container ports. As shipping lines managed their available capacity efficiently (Sect. 3), container ports responses have been multidimensional, with some of them undertaking a substantial reorganization in their operations. As detailed elsewhere (UNCTAD 2020a; Notteboom and Pallis 2020; IAPH-WPSP 2020), these adjustments included respecting sanitary protocols and other requirements imposed as a response to COVID-19, such as social distancing, longer shift changeover, cleaning equipment, and operational vehicles (ship-to-shore cranes, vans, side, and front loaders), rotation schemes, and a lower number of dockworkers per shift. Collaboration and coordination among stakeholders in combating risks and improving resilienceincluding the application of existing contingency plans and speeding up the use of technologies (digitalization)_facilitated quick responses to the crisis. The capacity of ports to adopt urgent and compensatory financial measures like cash flows for early payment of providers, constrained by lockdowns and suppressed demand, or delayed payments by some of their users, also contributed to mitigate the adverse effects of the crisis.

This allowed for the continuation of business activities and sustained maritime supply chain operations, even at the peak of the crisis in April-May 2020. The automation of services and the digitalization of port community exchanges have been instrumental, as they allowed ports to effectively reply to the conditions imposed by the crisis and by personnel shortages. However, since the early days of the

\footnotetext{
15 A considerable part of the paper was drafted in the midst of the second wave of the COVID19 pandemic. This explains our choice, or need, to frequently use the present tense in our narrative.
} 


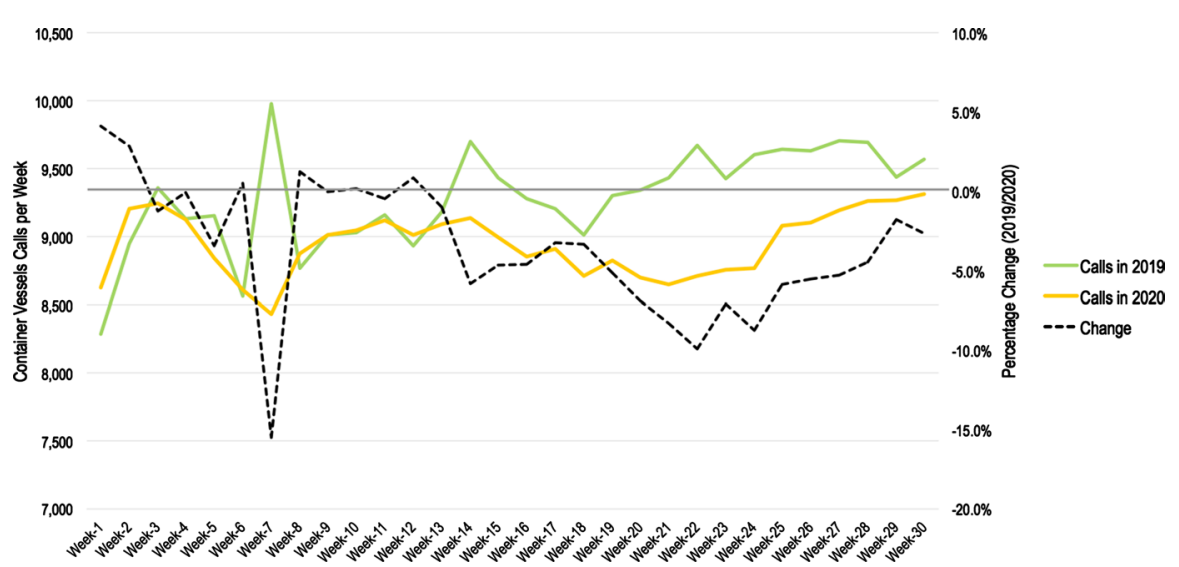

Fig. 9 Global container vessel calls per week (2020 versus 2019). Source: based on AIS data collected by Marine Traffic; analyzed by the authors in the context of UNCTAD (2020a)

COVID-19 crisis, container ports were confronted with additional challenges resulting from changes in port services demand.

\subsection{Container vessel calls}

The first of these additional challenges has been the lower number of port calls. In the first 30 weeks of 2020, container vessel calls in ports around the globe declined by 3.6\% compared with the same period in 2019 (Fig. 9). During Q1 2020, when the outbreak was more localized, the variations in vessel calls were marginal $(-1.1 \%)$, although this period includes the week with the biggest drop. In mid-February (week 7), the outbreak of COVID-19 in China resulted in $15.5 \%$ fewer vessel calls than in the same week of 2019. The conventional post-Chinese New Year boom of shipping activity did not take place. The picture changed in Q2 2020, when countries imposed economic and social restrictions and lockdowns, with the overall decline of calls standing at $6.1 \%$. Since then, the number of calls started to recover. In fact, vessel calls after week 27 already approached those of 2019.

A major difference compared with the 2008/2009 crisis were the regional variations in the magnitude of vessel call reductions and their timing. Australasia and Oceania $(-11.5 \%)$ and Sub-Saharan Africa $(-11.3 \%)$ have been impacted the most (Fig. 10). Lower containership capacity deployed in these two regions has been evident since the beginning of the year. In countries more distant from the point of emergence (China), the pandemic began to be fully felt in Q2 of 2020. This was the case in Europe and North America, where the decline reached double-digit percentages ( $11.3 \%$ and $9.5 \%$, respectively) immediately after the WHO declared COVID-19 a pandemic in mid-March (week 12). In Q3 2020, the situation, which followed the same trends, improved with the decline in Europe, reaching $-6.8 \%$. Several restrictions in economic activities and local lockdowns continue to apply as of October 2020. This figure is just one percent higher than in North America (-5.8\%), where measures restricting economic activities 


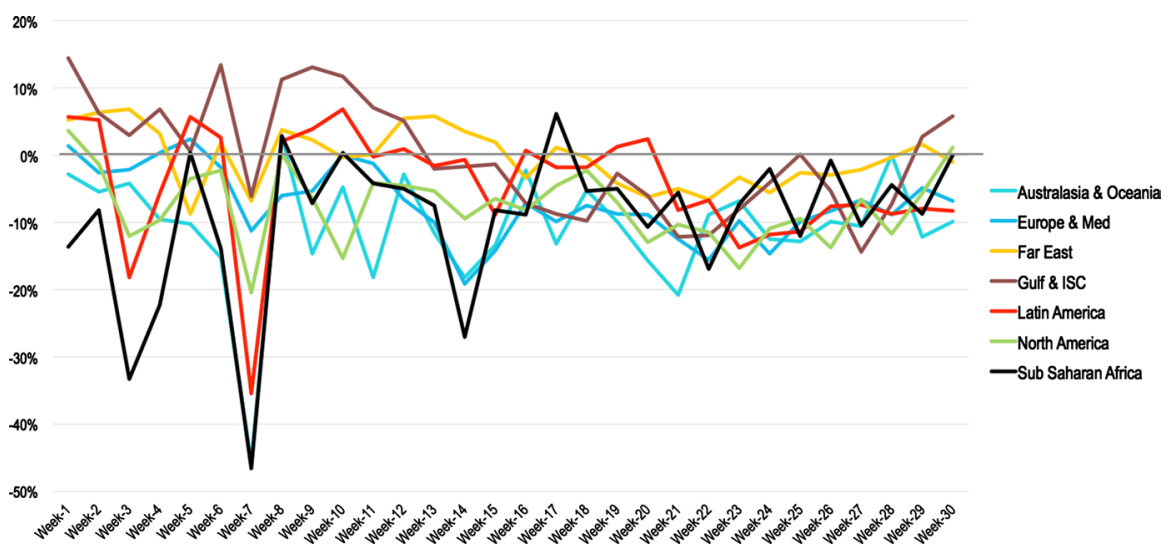

Fig. 10 Change in container vessel calls by region (2020 versus 2019). Note Data for 2020 are compared with the same weeks of 2019. Source: Based on AIS data collected by Marine Traffic; analyzed by the authors in the context of UNCTAD (2020a)

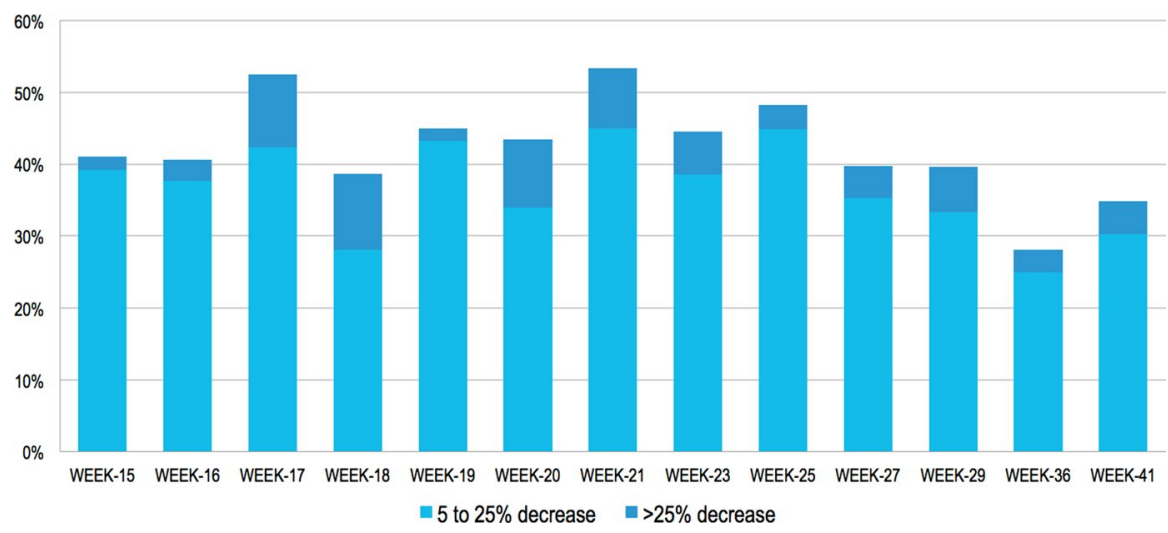

Fig. 11 Share of container ports affected by blank sailings. Source: based on results of WPSP-IAPH surveys on the impact of COVID-19 on world ports as reported in Notteboom and Pallis (2020)

substantially varied across states. As the crisis reached Latin America at a chronologically later stage, the decline of container vessel calls in the region was mild $(-3.7 \%)$ in Q1 2020, increased in Q2 2020 (-5.3\%), and fell most since then $(-8.1 \%)$.

The variance in port call declines is witnessed at the port level as well. The percentage of container ports that experienced a lower number of calls each week since COVID-19 was classified as a pandemic in mid-March 2020 until July 2020 exceeded $40 \%$ (Fig. 11). However, the number of ports that experienced a severe disruption standing at more than a $25 \%$ decrease in weekly calls compared with normal has been less than $10 \%$. The same data underline that, in Q3 2020, container ports experiencing fewer calls stand at lower than $35 \%$ of all, despite the 


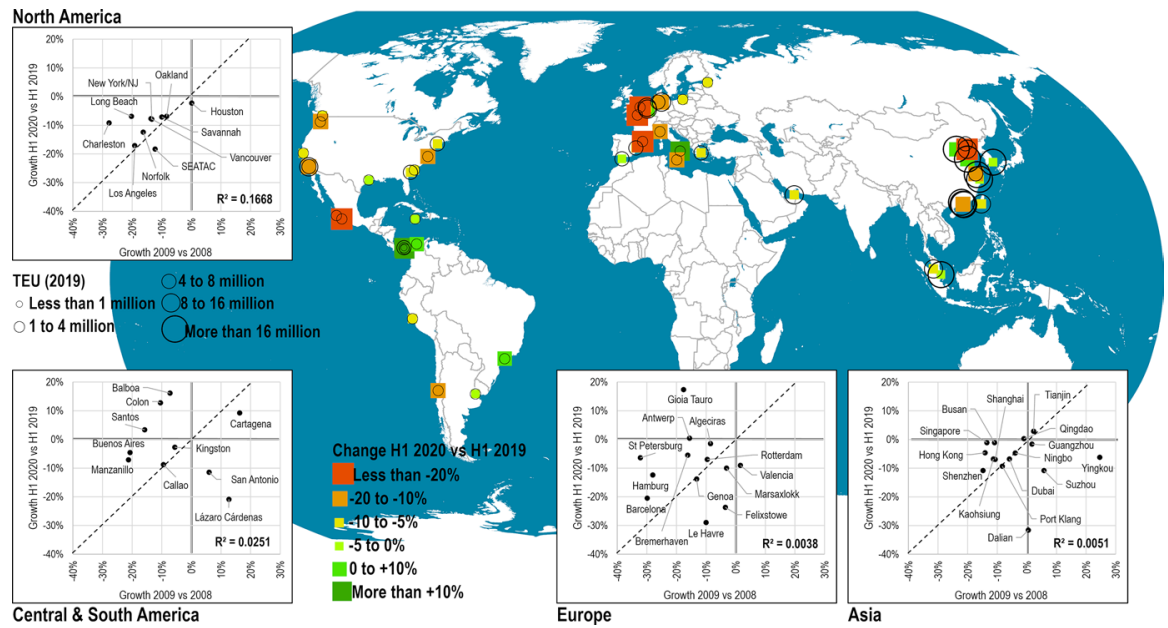

Fig. 12 Growth of container traffic at major container ports H1 2019/H1 2020 versus 2008/2009. Note Gdansk (Poland) and Piraeus (Greece) are not included in the European map given their very strong growth as upcoming container ports in 2009 (47\% and 91.7\%, respectively). However, their strong growth pattern of the past decade came to an abrupt end in H1 2020 as they both suffered traffic losses of $-6.5 \%$ and $-6.2 \%$, respectively. Source: Authors

significant pressures generated by the second wave of COVID-19 cases on several economies (mostly in Europe).

The recorded decline in container vessel calls was affected by a series of blank sailings in long-haul liner services, which can serve as an indicator of changes in demand. In recent years, a correlation between blanked capacity and decline in demand has been observed, as carriers have become better at capacity management (see analysis in Sect. 3). With further structural transformations of liner shipping networks underway (Sect. 6), and given the discrepancy of national policy initiatives to combat the resurgence of COVID-19 cases, it remains to be seen whether the decline in vessel calls will persist in the long-term, and whether the regional variations observed will endure or increase even further.

\subsection{Cargo volumes}

The container volumes handled in ports amidst the COVID-19 pandemic were less impacted than the number of containership calls. A database of TEU volumes growth (decline) in $\mathrm{H} 12$ 2020, for a port sample capturing more than $50 \%$ of all container volumes in each regional market (i.e., Asia, Europe, Latin America, and Caribbean; North America) was constructed. The database contains the biggest container ports in each geographical region, and data were collected via the websites of port authorities and occasionally via direct requests. This representative sample illustrates the comparatively lower decline in throughput (Fig. 12). The year-on-year TEU growth in the first half of 2020 also reveals (a) significant differences among the larger container ports, (b) eight ports recording growth in H1 2000, three of 
them at a double-digit level, (c) a total of 17 ports recording a slight decline of less than $5 \%$, and (d) that only a small number of ports is experiencing a major decline in 2020 compared with 2019.

When these ports are split into groups according to size (Table 2), the biggest ports of the world (i.e., those handling more than 10 million TEUs per year), have experienced, on average, a smaller decline $(-4 \%)$ than ports handling 3-10 million TEUs per year $(-10 \%)$, with Shenzhen being the only of the 14 ports recording a double-digit decline.

The result is notable because it occurred in a period where, for many shippers and forwarders, pickup of import cargo from the port was particularly challenging, or even undesirable due to limitations in hinterland transportation. This particularly concerned cross-border crossing complications caused by new measures, or shortage of truck-drivers and temporary suspension of rail and barge services. Business at ports was further maintained since shipping lines started using some of the world's leading transshipment hubs (such as Bremerhaven, Busan, Panama, etc.) as advance yard storage to convince shippers to begin moving goods early in anticipation of a demand recovery (MSC 2020). As discussed in Sect. 2, shipping lines offering flexible storage solutions to shippers not only minimized booking cancellations, but also helped limiting congestion in ports of discharge, thus improving efficiency, as products were placed closer to distribution networks. However, at the same time, shippers generating substantial container traffic (e.g., major retailers such as Arcadeia, C\&A, Gap, Levi Strauss, Walmart, etc.) were among those that made no immediate commitment to collect and transport orders completed, stored, and in production.

Among the sample ports, there is no correlation between traffic changes occurring during the 2008-2009 financial crisis and during H1 of COVID-19, either at a regional or global level. This implies that, even if corresponding drops in container volumes were observed, the pattern is significantly different. At regional level, the changes in container traffic patterns observed during the financial crisis cannot be used as a predictor for the potential impacts of COVID-19 on ports and shipping networks. For an external shock such as COVID-19, its impacts are the outcome of how individual ports fit within complex supply chains. Figure 12 underlines that the ports that have been impacted the most tended to be linked with supply chains embedded within the Asia trade, particularly trade gateways. The pattern suggests that container traffic declines are associated with the cargo composition, with ports depending on discretionary and durable goods impacted more than ports having a more complex cargo base, in line with the conceptualization visualized in Fig. 1. Similar findings concerning the consequences of the 2008/2009 financial crisis on European ports throughput underlined variations according to cargo type (Pallis and de Langen 2010). The composition of containerized trade, which is difficult to measure, stands as a key factor in the differential in port traffic across the sample (Rodrigue and Notteboom 2015).

In Europe, Antwerp was the only gateway port recording positive growth in H1 2020. The port has benefited from its strong focus on containerized basic goods and commodities, less affected by the crisis (Fig. 1), as well as from its position as a north European hub in the shipping network of MSC. On the other hand, Le Havre, Barcelona, Hamburg, and Genoa appeared to be rather vulnerable to the two 


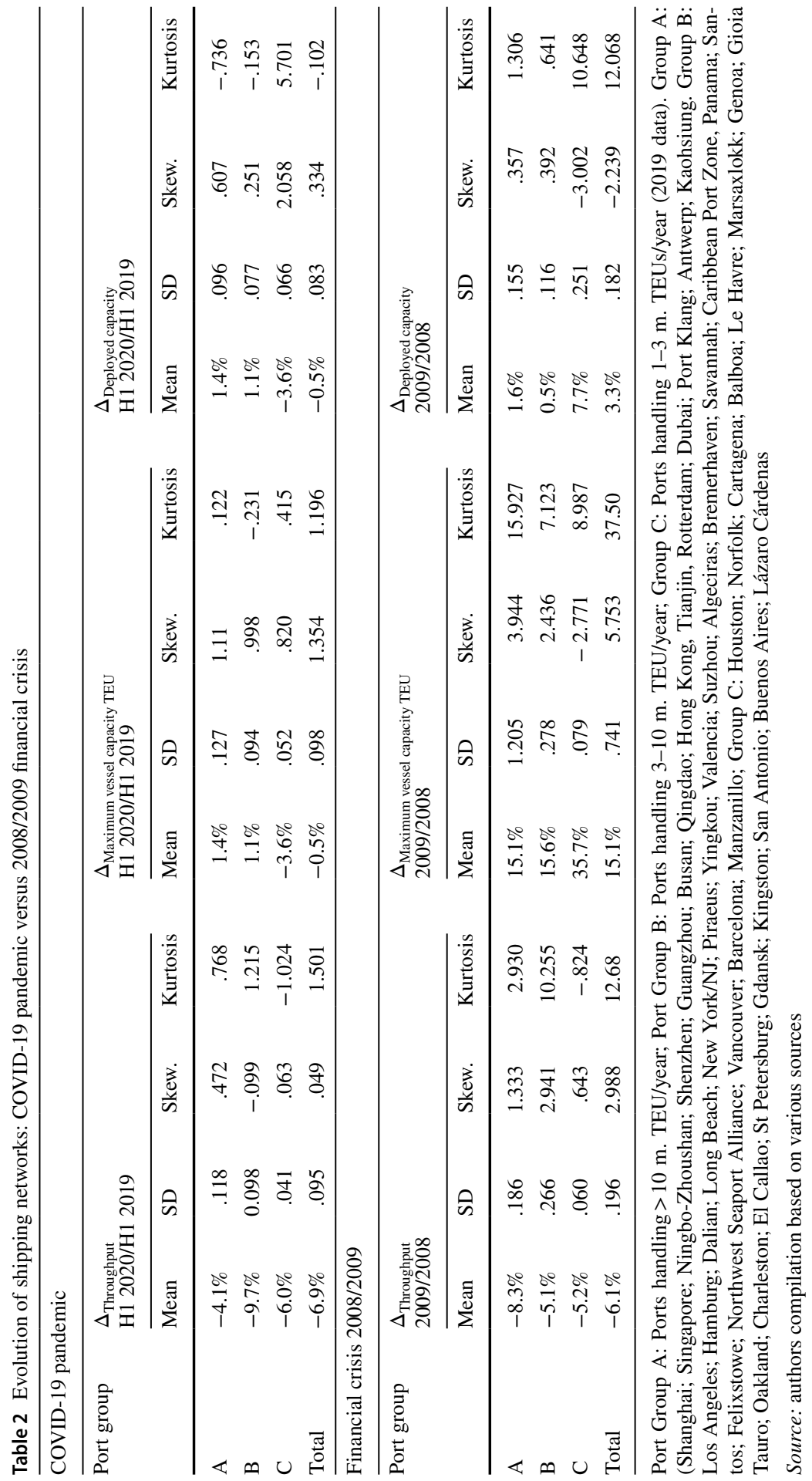


crises. These are all gateway ports serving mainly national hinterlands which are subjected to intense competition for transshipment flows, and with a strong specialization in containerized consumer products mainly originating from Asia. While in Asia, many ports experienced similar volume impacts during both crises, Busan and Singapore are hardly affected by COVID-19. The Latin American sample confirms that a port's dominant location in a specific region might be valuable even in crisis conditions for some ports. For instance, the Colombian port of Cartagena has maintained. In North America, the Pacific ports of Los Angeles and Seattle/Tacoma have been the most vulnerable during both crises under examination. At the same time, the industrial hub of Houston is the only North American port where both crises have had little impact.

However, for some ports, the trends in handling cargoes were determined by broader developments than solely by the crisis. The growth recorded in 2020 at the transshipment hub of Gioia Tauro, for instance, was caused by the takeover of the Medcenter container terminal by MSC in late 2019, positioning the port as one of its main hubs in the Mediterranean Sea. Similarly, the rising stars of Piraeus and Gdansk, which did not manage to keep growing in H1 2020, had recorded a remarkable growth during the financial crisis of 2008/2009, as this coincided with major governance and ownership changes in both ports.

As the rationalization of liner services continues, shipping companies face a more comprehensive review of their port calls and network configurations. Port pricing plays an essential role in this reconfiguration, with larger ports, possessing more developed hinterland transport systems, more resilient than small and medium-sized ports. Also, ports that have balanced traffic are likely to be less impacted. However, it is not entirely clear that sustained declines in traffic could be a factor of cargo concentration or deconcentration within port systems.

\section{Evolution of shipping networks: aspects of connectivity}

\subsection{Handling larger vessels}

Shipping lines have responded to both the financial crisis of 2008-2009 and COVID-19 through changes in their carrying capacity and the deployment practices (Figs. 13, 14). When the demand is uncertain and margins are declining, shipping lines try to fall back on economies of scale, which are not void of negative impacts, such as creating surplus capacity and depressing rates (see Haralambides 2019, for the implications of ship gigantism). The major difference is that, during COVID-19, shipping lines were far more effective in managing their aggregate carrying capacity than during the financial crisis, allowing for rate stability in light of uncertain demand.

The maximum size of the deployed container vessels continued to increase despite the pandemic (Fig. 13). However, the scale increase has been considerably less significant than during the 2008/2009 financial crisis (Table 2). In 2008/2009, both the deliveries of newbuilds and the orderbook were subject to optimistic forecasts. 


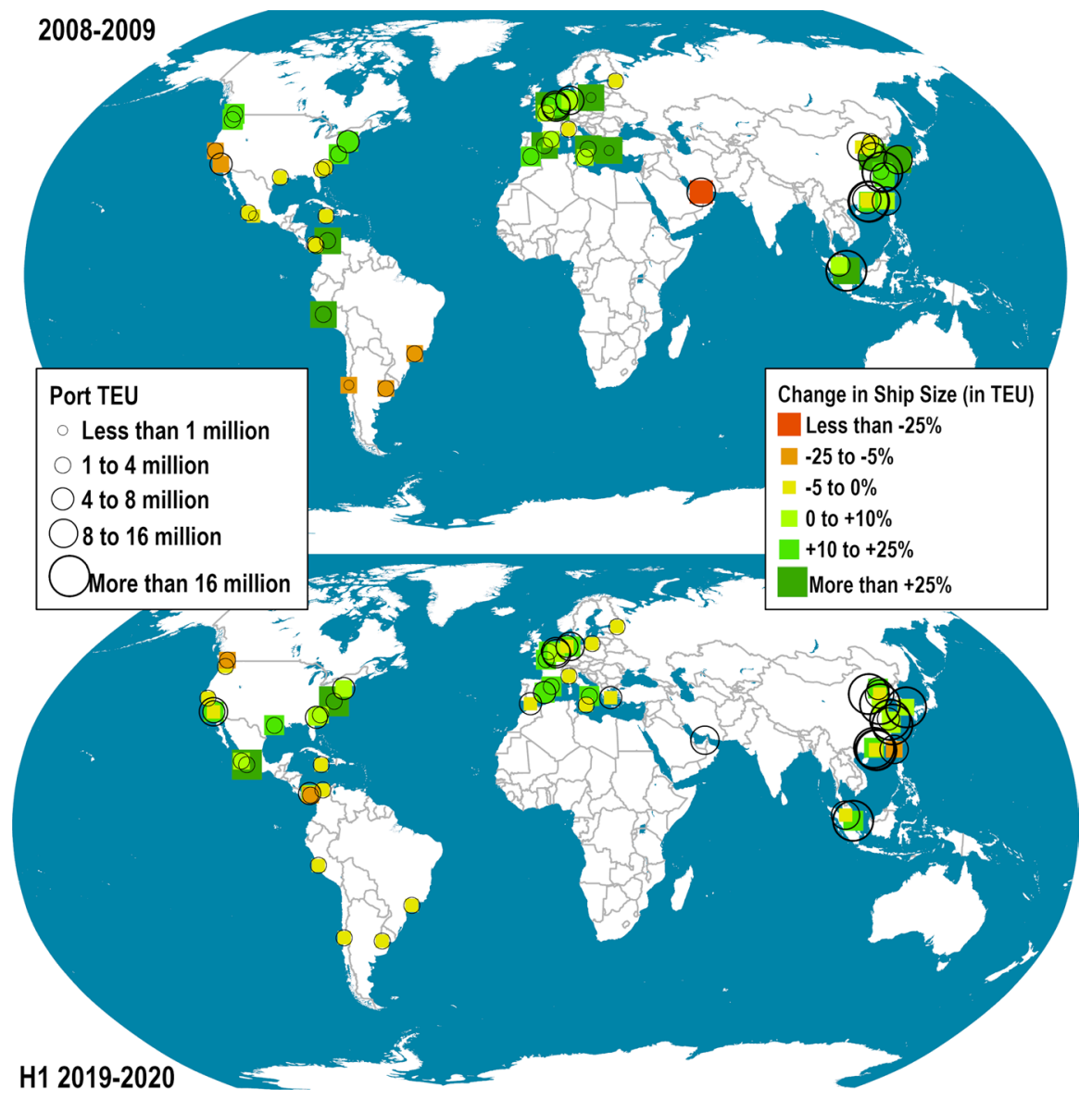

Fig. 13 Increase of size of the largest calling container vessel at major ports H1 2019/H1 2020 versus 2008/2009. Source: Authors

This time the source of pressures on ports was of a different nature. Port calls by ultra-large container ships (ULCS) may have declined in numbers, but volume surges accompanied this decline during port calls. Capacity management, along with digitalization (e.g., advanced information exchange) and vessel stowage planning procedures have all been leveraged to maximize vessel utilization. Alliances reported increased loading of ULCSs (Sect. 3), adding more pressure on ports and maritime supply chains, as they hosted fewer vessel calls with substantially more cargoes handled per port call. The outcome of this has been a concentration of cargoes and volumes at port calls. Major container ports in North America and Europe reported that the average number of moves per call reached 10,000 TEUs 


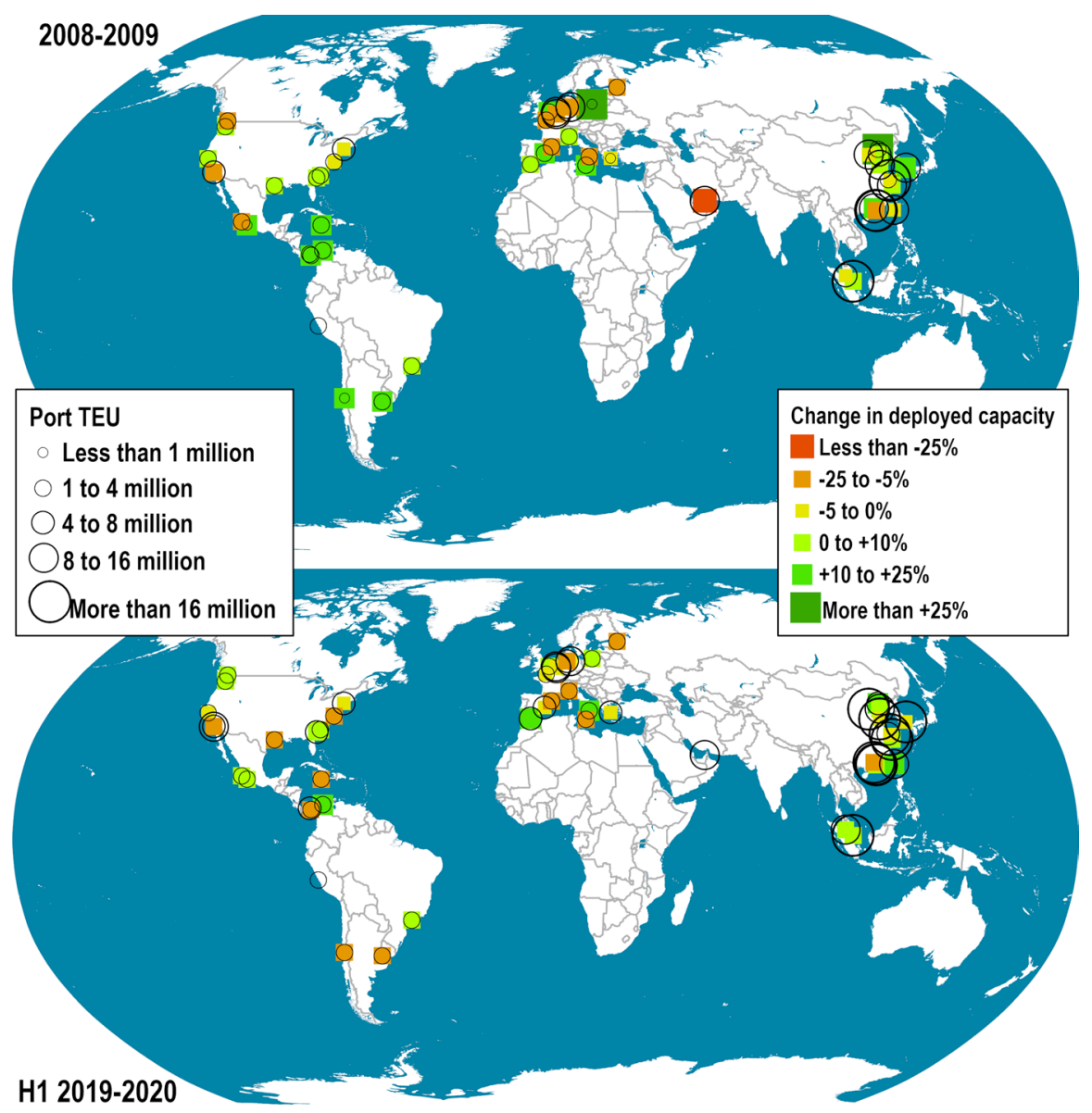

Fig. 14 Change in the deployed capacity of container vessels at major ports H1 2019/H1 2020 versus 2008/2009. Source: Authors

in the first half of $2020,{ }^{16}$ creating peaks in ship-to-ship operations and yard activity, gate congestion, and other operational challenges for terminals. The situation is also impacting landside operations, as notification systems and cargo release for hinterland transportation become burdened. Ports took time to adjust their yard and gate operations, and often this has led to inefficiencies in terminal operations, such as the management of container stacking. Even the workforce was under pressure as peaks of intense activity were followed by days of relative inactivity. Further adjustments, such as finding new storage and cargo forwarding solutions, are crucial in

\footnotetext{
${ }^{16}$ In the first half of 2020, several call size records have been broken. For example, 34,263 TEUs were handled when MSC Isabella called at the port of Los Angeles in June 2020. A total of 21,500 TEU were handled from the MSC Kalina in Singapore in April 2020, and 18,059 TEU were handled on MSC Mina calling at Antwerp in June 2020.
} 
keeping maritime trade flowing, which is important for many ports, given the risk for over-utilization of existing facilities and the need for new storage and warehousing capacity.

\subsection{Deployment patterns}

A negative trend has been observed across all components associated with liner shipping connectivity levels. ${ }^{17}$ The number of liner shipping services, weekly port calls, liner shipping operators, vessel carrying capacity deployed, and direct calls have all dropped in the first half of 2020, with wide variations at regional level. In Asia and Oceania, ports experienced a moderate decrease in connectivity levels. Even though China was the first country to face the challenges caused by the COVID-19 pandemic, the initial negative effect of Chinese ports on liner shipping connectivity was relatively moderate. Europe, which at the time of writing is enduring the second wave, has seen substantial drops in liner shipping connectivity levels. In North America, the picture is mixed. The West Coast ports have experienced significant negative trends, especially during the second quarter of 2020. The impact was not as severe on the East Coast. In Central and Latin America, container ports showed signs of resilience. Their liner shipping connectivity levels remained steady and, in some cases, increased during the early days of the pandemic. African ports also performed comparatively well. While the change in the deployed capacity is not (yet) of significant scale as a percentage, its importance should not be underestimated (Fig. 14) as short-term trends indicate that the biggest ports of all seem to provide a more attractive option for liner shippings compared with other ports, and have attracted further capacity deployment than smaller ports.

\section{Conclusions}

Resilience to disruption remains a core challenge for the global shipping and port industries. Along with standard business cycles, the industry has continuously faced differentials in growth rates and a decline in shipping activity. A crisis represents an event involving a large amount of stress with sudden adjustments in expectations, to which the industry is forced to react. Each crisis becomes an opportunity to test the adaptability of the shipping and port industry to rapidly shifting circumstances.

Due to its inherent cyclicity, shipping is not unfamiliar with global crises. The immediate past crisis (the financial tsunami of 2008/2009) was "a crisis waiting to happen", with shipping and related markets "ignoring signals to an imminent inflection point" (Haralambides and Thanopoulou 2014). The core difference between the COVID-19 pandemic and the financial crisis of 2008-2009 resides

\footnotetext{
17 Our study discusses two aspects of liner connectivity in detail, namely maximum size (TEU) of container ships visiting a port and the deployed capacity per port. For information on other parameters associated with liner shipping connectivity (such as number of shipping services, weekly port calls, shipping operators, direct calls) see UNCTAD (2020a) and UNCTAD (2020b).
} 
in the externality of the causal factors of the former. As its namesake states, the financial crisis was derived from weaknesses internal to the financial system, particularly asset inflation and the related malinvestments. There were several warning signs that both the industry and its analysts chose to ignore or discount. It took several years for the global economy to recover from the resulting recession. COVID-19 was an external shock with few (short-term) warning signs, suddenly impacting supply chains, trade, and shipping through forward and backward propagation mechanisms. Therefore, it was observed that, although at the aggregate level, the financial crisis and COVID-19 appear to have similar impacts, these impacts do not show similar patterns across ports and shipping networks.

The study identified several differences in adaptation mechanisms (resilience) that the shipping industry has used to adapt to shocks. Capacity management in container shipping, through a concerted effort to align shipping capacity with volatile market demand, had very different outcomes during the two crises. Unlike the financial crisis, where shipping lines could not effectively manage their collective capacity therefore resulting in substantial rate erosion, poor vessel utilization levels, and bailouts, COVID-19 reconfirmed the market position and bargaining power of shipping lines, with an upsurge in freight rates and a positive impact on financial results.

The consolidation wave of 2014-2017 and alliance formation have facilitated the unfolding of this strategy. Slow steaming, adopted during the financial crisis of 2008-2009 in an attempt to absorb excess capacity, could not be used as a tool during the pandemic. However, the reliance on economies of scale, allowing shipping lines to rationalize services and cost structure by deploying larger ships and idling smaller ones, turned out to be effectively applied in both the financial crisis and COVID-19. Both events resulted in a push towards scale, and our study revealed that, this time, this phenomenon was less intense than during the financial crisis. Even if these two events were completely different, shipping lines were better prepared to cope with the pandemic because of the lessons learned from the financial crisis, and also because of a more effective joint capacity management through alliances. The core lesson is that capacity management is a robust resilience strategy for the shipping industry to mitigate disruptions. Since maritime transportation serves a derived demand, the risk is that the external supply chain shock brought by COVID19 could become internalized within the global economy, having long-term impacts on demand. Therefore, what happened during the financial crisis of 2008-2009 could follow the initial disruptions brought by COVID-19.

Global terminal operators adapted much earlier to the imperatives brought by the two economic shocks. The financial crisis incited these actors to reassess risks and move away from previous, aggressive expansion strategies (Rodrigue et al. 2011). A decade ago, terminal facilities ownership and even the continuation of operations were revisited by terminal operators and financial institutions that had experienced a high entry cost in the container market. Not only did global terminal operators financially outperform container shipping lines, but they also managed to keep positive EBITDA margins during the financial crisis and the COVID-19 pandemic. This is partly the result of a range of rationalization strategies, including intensified cost control, cancellation, or postponement of terminal acquisition or construction 
projects, and by spreading market risks through the use of more complex terminal ownership and partnership structures. Ports continue to be considered long-term investments, and the COVID-19 pandemic will not impact this assessment.

In conditions of lower, at times non-existent, demand and halted economic activity, ports and terminal operators demonstrated notable operational adaptability to events, including those that might prove to be more structural than temporal ones. Ports had to serve a lower number of vessel calls without, however, the steep decline of calls that followed the earlier financial shock. The utilization levels of containerships went up this time, contrary to 2008/2009. The operating challenges generated by bigger and more utilized vessels, with cargoes frequently stored longer at the yard following shipping lines/shippers requirements, were met effectively, even though new working protocols (sanitary needs, social distancing, teleworking of administrative personnel, shortages of dockworkers) obliged them to adopt new operating principles.

The operational changes in dockwork operations (i.e., automation), administration, and port community interactions (e.g., the need for paperless transactions within ports, and associated hinterland and cross-border operations) resulted in an immediate response to the "new normal" imposed by the COVID-19 crisis. These developments accelerated changes in port management practices (Notteboom and Haralambides 2020), digitalization and automation, and in recently endorsed port governance models (see: Brooks et al. 2017) as means to sustain and increase the resilience of maritime supply chains.

We found no correlation between traffic changes occurring during the 2008-2009 financial crisis and those that took place in H1 2020, either at a regional or global level. This leads us to believe that container traffic dynamics observed during the financial crisis cannot be used as a predictor for the potential impacts of COVID19 on ports. At the same time, the COVID-19 impact varied per region as well as per port (i.e., container cargo handled, size of vessels deployed, aggregate deployed capacity). The large diversity in traffic patterns and connectivity levels among ports means that the vulnerability of ports is largely dependent on the cargo mix, the port call choices of carriers, and the position of the port in the global shipping network and in its hinterland.

The examination of the short-term impacts of COVID-19 and the comparison with those of the 2008/2009 financial crisis revealed the idiosyncratic implications of each crisis on maritime supply chains. It also revealed a notable resilience of all three industries examined. Shipping lines, terminal operators, and ports have all demonstrated an increased resilience, partly supported by the rediscovery of risks in the aftermath of the $2008 / 2009$ crisis, and partly by the organizational changes in each of these industries. While research on the long-term impacts of COVID-19 will develop in due time, our findings confirm that each crisis also stands as a background for structural changes and opportunities for improvements. 


\section{References}

Alphaliner. 2010. Weekly Newsletter, 2010 (7).

Alphaliner. 2010a. Weekly Newsletter, 2010 (8).

Baschuk, B. 2020. World Trade Hit by Virus Sees Worst Collapse in a Generation, Bloomberg. March $26,2020$.

Bems, R., R. Johnson, and K. Yi. 2010. Demand Spillovers and the Collapse of Trade in the Global Recession. IMF Economic Review 58: 295-326.

Bhaskar, P., S. Cahoon, and S.L. Chen. 2019. Shipping Companies' Resilience: The Influence of Modularity and Response Diversity. In Proceedings of the 4th Belt and Road Initiative Conference 2019, $1-15$.

Brooks, M.R., K.P. Cullinane, and A.A. Pallis. 2017. Revisiting Port Governance and Port Reform: A Multi-country Examination. Research in Transportation Business \& Management 100 (22): 1-10.

Chen, J.H., D.J. Zeng, and J. Wang. 2012. Developing Trends and Strategies of International Container Shipping Industry During the Period of the Financial Crisis. Logistics Engineering and Management 34 (8): 1-3.

Crotti, D., C. Ferrari, and A. Tei. 2019. Merger Waves and Alliance Stability in Container Shipping. Maritime Economics \& Logistics 22 (1): 1-27.

De Monie, G., J.-P. Rodrigue, and T. Notteboom. 2010. Economic Cycles in Maritime Shipping and Ports: The Path to the Crisis of 2008. In Integrating Seaports and Trade Corridors, ed. P. Hall, R. Mc Calla, C. Comtois, and B. Slack, 13-30. Surrey: Ashgate.

Drachal, K. 2016. Forecasting Spot Oil Price in a Dynamic Model Averaging Framework-Have the Determinants Changed over Time? Energy Economics 60: 35-46.

Drewry. 2010. Global Container Terminal Operators: Annual Review and Forecast. London: Drewry.

Drewry. 2019. Global Container Terminal Operators: Annual Review and Forecast. London: Drewry.

Fusillo, M. 2006. Some Notes on Structure and Stability in Liner Shipping. Maritime Policy and Management 33 (5): 463-475.

Fusillo, M., and H. Haralambides. 2020. Do Carrier Expectations Indicate Industry Structure in Container Shipping? An Econometric Analysis. Journal of Shipping and Trade 1: 12. https://doi.org/10.1186/ s41072-019-0057-2.

Graham, M.G. 1998. Stability and Competition in Intermodal Container Shipping: Finding a Balance. Maritime Policy and Management 25: 129-147.

Haralambides, H.E. 2019. Gigantism in Container Shipping, Ports and Global Logistics: A Time-lapse into the Future. Maritime Economics \& Logistics 21 (1): 1-60.

Haralambides, H.E., and H. Thanopoulou. 2014. The Economic Crisis of 2008 and World Shipping: Unheeded Warnings. SPOUDAI Journal of Economics and Business 64 (2): 5-13.

Hoff, K., and J.E. Stiglitz. 2001. Modern Economic Theory and Development. In Frontiers of Development Economics: The Future in Perspective, ed. G. Meier and J. Stiglitz, 389-459. Oxford: Oxford University Press.

IAPH-WPSP. 2020. WPSP COVID-19 Guidance Document for Ports. Antwerp: IAPH.

Knowler, G. 2020a. Extent of Chinese Factory Slump Supports Fears over Inventory Levels. Journal of Commerce, March 4, 2020.

Knowler, G. 2020b. Alliances Outline Extensive Blank Sailings for Q3. Journal of Commerce, June 3, 2020.

Leonard, M. 2020. Blank Capacity Nears 4 M TEUs with Carriers Planning Q3 Cancellations. SupplyChaindive.com, June 8, 2020.

Luke, T.C., and J.-P. Rodrigue. 2008. Protecting Public Health and Global Freight Transportation Systems during an Influenza Pandemic. American Journal of Disaster Medicine 3 (2): 99-107.

Meditteranean Shipping Company (MSC). 2020. Suspension of Transit. Geneva: MSC.

Mintel International. 2009. Brands-Are Supermarkets Squeezing Out Brands?. UK: Mintel International Group Ltd.

Notteboom, T. 2012. Container Shipping. The Blackwell Companion to Maritime Economics, 230-261. Chichester: Wiley.

Notteboom, T., and A.A. Pallis. 2020. WPSP/IAPH COVID-19 COVID-19 Port Economic Impact Barometer, September 2020. Antwerp: IAPH.

Notteboom, T., and H.E. Haralambides. 2020. Port Management and Governance in a Post-COVID-19 Era: Quo Vadis? Maritime Economics \& Logistics 22: 329-352. 
Notteboom, T., and J.-P. Rodrigue. 2012. The Corporate Geography of Global Container Terminal Operators. Maritime Policy \& Management 39 (3): 249-279.

Notteboom, T., J.-P. Rodrigue, and G. De Monie. 2010. The Organizational and Geographical Ramifications of the 2008-09 Financial Crisis on the Maritime Shipping and Port Industries. In Integrating Seaports and Trade Corridors, ed. P. Hall, R. McCalla, C. Comtois, and B. Slack, 31-46. Surrey: Ashgate.

Notteboom, T., and J.S.L. Lam. 2014. Dealing with Uncertainty and Volatility in Shipping and Ports. Maritime Policy and Management 41 (7): 611-614.

Notteboom, T.E., and B. Vernimmen. 2009. The Effect of High Fuel Costs on Liner Service Configuration in Container Shipping. Journal of Transport Geography 17 (5): 325-337.

Notteboom, T.E., F. Parola, G. Satta, and A.A. Pallis. 2017. The Relationship Between Port Choice and Terminal Involvement of Alliance Members in Container Shipping. Journal of Transport Geography 64: 158-173.

Olivier, D., F. Parola, B. Slack, and J.J. Wang. 2007. The Time Scale of Internationalisation: The Case of the Container Port Industry. Maritime Economics \& Logistics 9 (1): 1-34.

Pallis, A.A., and P.W. de Langen. 2010. Seaports and the Structural Implications of the Economic Crisis. Research in Transportation Economics 27: 10-18.

Pallis, A.A., T.E. Notteboom, and P.W. De Langen. 2008. Concession Agreements and Market Entry in the Container Terminal Industry. Maritime Economics \& Logistics 10 (3): 209-228.

Parola, F., and E. Musso. 2007. Market Structures and Competitive Strategies: The Carrier-Stevedore Arm-Wrestling in Northern European Ports. Maritime Policy \& Management 34 (3): 259-278.

Parola, F., T. Notteboom, G. Satta, and J.-P. Rodrigue. 2013. Analysis of Factors Underlying Foreign Entry Strategies of Terminal Operators in Container Ports. Journal of Transport Geography 33: 72-84.

Parola, F., T. Notteboom, G. Satta, and J.-P. Rodrigue. 2015. The Impact of Multiple-Site Acquisitions on Corporate Growth Patterns of International Terminal Operators. International Journal of Shipping and Transport Logistics 7 (5): 621-648.

Pelagidis, T., and H. Haralambides. 2020. What Shipping Can Tell Us About Europe's Efforts to Face the Risk of COVID-19-Induced 'Japanification'. World Economics 21 (3): 29-39.

Rodrigue, J.-P., and T. Notteboom. 2015. Looking Inside the Box: Evidence from the Containerization of Commodities and the Cold Chain. Maritime Policy and Management 42 (3): 207-227.

Rodrigue, J.-P., T. Notteboom, and A.A. Pallis. 2011. The Financialization of the Port and Terminal Industry: Revisiting Risk and Embeddedness. Maritime Policy and Management 38 (2): 191-213.

Slack, B., and A. Frémont. 2005. Transformation of Port Terminal Operations: From the Local to the Global. Transport Reviews 25 (1): 117-130.

The Economist. 2020. The Changing Geopolitics of Energy: America's Domination of Oil and Gas Will Not Cow China, 17 September 2020.

Todo, Y., K. Nakajima, and P. Matous. 2015. How Do Supply Chain Networks Affect the Resilience of Firms to Natural Disasters? Evidence from the Great East Japan Earthquake. Journal of Regional Science 55 (2): 209-229.

UNCTAD. 2020a. COVID-10 and Maritime Transport: Impact and Responses. UNCATD/DTL/TLB/ NF/2020/1. Geneva: UNCTAD.

UNCTAD. 2020b. Review of Maritime Transpot 2020. Geneva: UNCTAD.

World Health Organization. 2020. Shortage of Personal Protective Equipment Endangering Health Workers Worldwide, News Release. Geneva: WHO.

World Trade Organization. 2020. Trade Set to Plunge as COVID-19 Pandemic Upends Global Economy, News Release. Geneva: WTO.

Yang, D., L. Jiang, and T. Notteboom. 2019. Innovative Solutions for Shipping Market Turmoil: The Search for Profitability, Sustainability and Resilience. Transport Policy 82: 75-76.

Publisher's Note Springer Nature remains neutral with regard to jurisdictional claims in published maps and institutional affiliations. 